\title{
Comparative Study on the Possible Protective Effect of Lepidium Sativum versus Teriparatide in Induced Osteoporosis in Adult Male Guinea Pigs
} Original Article

\author{
Hala EL-Haroun, Mona Soliman, Maha Soliman, Shimaa Abd El-Gawad
}

Histology Department, Faculty of Medicine, Menoufia University, Egypt

\begin{abstract}
Background: Osteoporosis is a major health problem. Teriparatide is a recombinant parathyroid hormone used as antiosteoporotic therapy. Lepidium sativum (LS) is widely used as a traditional herbal therapy for hypertension, diabetes and renal disorders. The LS seeds are widely known as a good traditional alternative medication for fracture healing.

Objectives: Current research focused on evaluation of the Lepidium sativum versus teriparatide effect on glucocorticoidinduced osteoporosis

Materials and Methods: 60 adult male guinea pigs were randomly divided into six equal groups: control groupI (distilled water); LS treated group ( $300 \mathrm{mg} / \mathrm{kg}$ suspended in distilled water orally by gastric tube), teriparatide treated group (4 mcg/ $\mathrm{kg}$ subcutaneously twice weekly), glucocorticoid treated group $(3.5 \mathrm{mg} / \mathrm{kg}$ subcutaneously), teriparatide and glucocorticoids treated group and glucocorticoids and lepidium sativum treated group as pervious groups. At the end of the study, animals were anaesthetized and sacrificed. Femur bones of each animal were excised for histological and immunohistochemical studies (caspase-3 and osteoponotin).

Results: Glucocorticoids induced bone resorption manifested as resorption cavities, thickened periosteum associated with decreased and irregular cortical and trabecular bone thickness. Marked reduced irregular collagen fibers were detected by trichrome staining.

Immunohistochemically, this group showed positive immunoreactivity for caspase- 3 in osteocytes and decrease in osteopontin deposits in bone matrix. Moreover, there was significant increase in number of osteoclasts associated with decrease in number of osteoblasts. Significant decrease in serum calcium level and increase in serum alkaline phosphatase were detected.

Administration of either teriparatide or Lipidium sativum with glucocorticoids improved biochemical, histological and morphometric bone changes. They reduced osteocytes apoptosis and osteoclasts increase. Lipidium sativum was more effective improving changes induced by glucocorticoids.

Conclusions: Glucocorticoids induced bone resorption. Despite the high cost of teriparatide, it did not achieve the desired protective effect. LS is cheap, available and its protective effect is promising with no adverse effects.
\end{abstract}

Received: 02 November 2019, Accepted: 13 January 2020

Key Words: Bone, lepidium sativum, teriparatide.

Corresponding Author: Hala EL-Haroun, PhD, Histology Department, Faculty of Medicine, Menoufia University, Egypt, Tel.: +20 1006601467, E-mail: elharoun@yahoo.com

ISSN: 1110-0559, Vol. 43, No.3

\section{INTRODUCTION}

Osteoporosis is a bone disorder distinguished by compromised bone strength leading to an increased risk of fracture. According to the World Health Organization (WHO) standard, osteoporosis is described as a low bone mineral density (BMD) that sets 2.5 standard deviation (SD) or more below the standard for juvenile healthy women as evaluated by dual energy $\mathrm{x}$-ray absorptiometry $(\text { DEXA })^{[1]}$.

Osteoporosis can be subdivided into primary osteoporosis which results from bone depletion due to hypo gonadal function related to aging, and Secondary osteoporosis which may be caused by chronic systemic diseases, endocrine and metabolic disorders, medication (glucocorticoids) and nutritional disorders ${ }^{[2]}$.
Glucocorticoids are one of the most prominent causes of secondary osteoporosis. Researchers proved that glucocorticoids (GCs) escalate the possibility of fracture and bone depletion ${ }^{[3]}$. Glucocorticoids (GCs) negatively affect bone through multiple pathways; proinflammatory cytokines induce bone resorption and reduce bone formation ${ }^{[4,5]}$. Glucocorticoids also cause osteoblastic dysfunction by shortening the period in which the osteoblasts work actively to form the bone matrix ${ }^{[6]}$. Kasem et al..$^{[7]}$ stated that the principal action of glucocorticoids is repression of osteogenesis by affection of differentiation and activity of many cell types. GCs modify the transcription of many of the genes bonded for the constitution of matrix components released by osteoblasts mainly type 1 collagen and osteocalcin (OC). They inhibit production of prostaglandins such as PGE2 
which normally stimulate collagen and non-collagenous protein synthesis.

Teriparatide is a recombinant protein of parathyroid hormone (PTH), consisting of 34 amino acids with $\mathrm{N}$-terminal end, which is the part of the hormone. It is a potent promoting bone genesis agent. Intermittent use of teripratide stimulates osteoblast activity rather than osteoclasts, which resulted in intensifying bone formation ${ }^{[8]}$. Teriparatide enhances bone formation and subsequently bone resorption. It increase cortical bone thickness as well as trabecular bearing and interlink ${ }^{[9]}$. Wang et al. ${ }^{[9]}$ explained that teriparatide can diminish the level of the cellular ROS and stimulate osteocytes growth via triggering the protein kinase $\mathrm{B}(\mathrm{PKB})$ pathway Meantime, the activated PKB can suppress caspase-3 proteolytic enzyme and stop the activation of apoptosis cascade. Teriparatide control the function of osteoblast via activation of the pathways signaling of cyclic AMP-dependent protein kinase A and calcium-dependent protein kinase $\mathrm{C}$. It also triggers the MAP kinase and phospholipase A and D pathways ${ }^{[10]}$.

Herbal medicine has frequently been utilized instead of chemical drugs due to its little adverse effects. Lepidium sativum is cultivated widely in the Middle East. It is mainly advised by ethno medicine for treatment of hypertension, diabetes management, renal disorders and phytotherapy. Lepidium sativum seeds are popular as a conventional medication for fracture healing ${ }^{[1]}$. The constructive influence of LS on bone density is probably due to its potentiality to raise liver and serum alpha linolenic acid (ALA), docosahexaenoic acid (DHA) and eicosapentaenoic acid (EPA) ${ }^{[12]}$, which have been proved to possess useful consequences on bone ${ }^{[13]}$. Several researchers have evaluated the effects of LS seeds ${ }^{[11]}$, as well as roots ${ }^{[14]}$ on bone strength and their pronounced impact on fracture healing.

Though, there is a lack of data related to the influence of Lepidium sativum on bone metamorphosis.

The formerly described advantages of LS seeds have aroused our attention to evaluate its capacity to manage osteoporosis. As teriparatide is a bone anabolic agent used for the treatment of osteoporosis, consequently, we focused on estimation of the protective roles of Lepidium sativum versus teriparatide on glucocorticoid-induced osteoporosis in adult male guinea pigs.

\section{MATERIALS AND METHODS}

\section{Animals}

Sixty adult male guinea pigs of average weight $450-500$ gm/each were used in the present study. Strict safekeeping and sanitation were maintained to keep them in normal and wellbeing conditions. Food and water were given adlibitum. Experimental guidelines were set by the Ethical Committee of Menoufia University.

\section{Chemicals}

Corticosteroids: was provided by Epico pharmaceutical Co., Egypt, as methyl prednisolone (Depo-Medrol) $40 \mathrm{mg}$ / $\mathrm{mL}$ suspension for injection.

Teriparatide: was provided by Lilly pharmaceutical Co., Egypt as Forteo $20 \mathrm{mcg} / 3 \mathrm{ml}$ solution for injection.

Lepidium sativum: obtained from local grocery in Menoufia.

$3 \mathrm{gm}$ Lepidium sativum seeds powder was suspended in $10 \mathrm{ml}$ distilled water. Seeds were administered orally through a gastric tube sleeved to a syringe ${ }^{[15]}$ at a dose 300 $\mathrm{mg} / \mathrm{kg}^{[16]}$

\section{Experimental Protocol}

The animals were randomly diverged into six groups included 10 animals for each as follows:

Group I (control group): control group was given distilled water orally for 4 weeks.

Group II (lepidium sativum-treated group): Animals were administrated lepidium sativum orally [15] at a dose $300 \mathrm{mg} / \mathrm{kg}$ for 4 weeks $^{[16]}$. Each animal received $0.5 \mathrm{ml}$ lipidium sativum suspension.

Group III (teriparatide treated group): They were injected subcutaneously with teriparatide at a dose of 4 $\mathrm{mcg} / \mathrm{kg}$ subcutaneously twice weekly for 4 weeks $^{[17]}$. Each animal received $0.3 \mathrm{ml}$ of Forteo.

Group IV (glucocorticoids treated group): They were administered methyl prednisolone $3.5 \mathrm{mg} / \mathrm{kg}$ per day for 4 weeks subcutaneously. Each ampule of methylprednisolone was diluted in $6 \mathrm{ml}$ saline. Each animal received $0.3 \mathrm{ml}^{[18]}$.

Group V (glucocorticoids and triparatide treatedgroup): They were injected subcutaneously (s.c.) with methylprednisolone $3.5 \mathrm{mg} / \mathrm{kg}$ per day for 4 weeks and teriparatide at a dose of $4 \mathrm{mcg} / \mathrm{kg}$ subcutaneously twice weekly for 4 weeks ${ }^{[17]}$.

Group VI (glucocorticoids and lepidium sativumtreated group): They were injected subcutaneously daily for 4 weeks ${ }^{[18]}$, concomitant with lepidium sativum orally ${ }^{[15,16]}$.

At the end of the study (4 weeks), blood specimens were withdrawn from the heart under anesthesia. Serum was used to measure serum calcium and alkaline phosphatase using spectrophotometer at Menoufia clinical pathology laboratory. Animals were then anaesthetized and sacrificed. Femur bones of each animal were excised. Half of the specimens of each group were fixed in $1 \%$ glutaraldehyde in phosphate buffer for scanning electron microscopic Study (SEM), and the other half were fixed in $10 \%$ formal saline then decalcified in EDTA (ethylene diamine tetra-acetic acid). After complete decalcification, specimens were processed for histological study. 


\section{Histological and Histochemical Study}

Paraffin sections of five $\mu \mathrm{m}$ thickness were cut and processed for Haematoxyline and eosin (H. \&E.) $\operatorname{stain}^{[19]}$ for standard histological investigation and with Mallory trichrome ${ }^{[20]}$ stain for distinguishing of collagen fibers. Samples were processed for histological assessment at Histology Department, Menoufyia University.

\section{Immunohistochemical Study}

Samples were processed for histological assessment at Histology Department, Menoufyia University.

\section{Caspase- 3}

Apoptosis in bone cells was examined by caspase-3 immunostaining. Inspection of active caspase- 3 was done applying a monoclonal antibody raised against human caspase-3 (anti-human/goat caspase-3 Active AF835; R\&D Systems, Minneapolis, MN). Antigen exposing was carried out by heating tissue sections in sodium citrate. Left to cool down, then, tissue sections were handled with $3 \%$ $\mathrm{H} 2 \mathrm{O} 2$, washed in phosphate-buffered saline) PBS), and then incubated with primary antibody for 18 hours at $4^{\circ} \mathrm{C}$. After washing, the slides were incubated with biotinylated secondary antibody rabbit polyclonal antibody IgG (Cell signaling Technology, Ipswich, MA) then washed again. Fixation of the primary antibody-biotinylated, second antibody complex was accomplished using a diaminobenzidine (DAB) reaction. To allow imaging of the tissue structure, specimens were gently counterstained with hematoxylin before cover-slipping. Normal lymphatic tissue was utilized as positive control. Negative control was executed by excluding primary antibody step so no immune- reaction was found ${ }^{[21]}$.

\section{Osteopontin $^{[22]}$}

Presence and distribution of the extracellular osteopontin protein expression in the bone matrix was detected. Osteopontin is important to cell-matrix interaction. Five $\mu \mathrm{m}$ paraffin sections were incubated with the diluted primary Antibody- Goat Anti-Rabbit IgG (NCL-O-PONTIN) (Novocastra) using the avidin biotin peroxidase method. Rabbit polyclonal antibody was used as 2ry antibody. Gastric carcinoma was used as positive Control. Negative control was executed by excluding primary antibody step so no immune- reaction was found.

\section{Scanning Electron Microscopic Study ${ }^{[23]}$}

The samples of left femurs were submerged in $2.5 \%$ glutaraldehyde, cleaned five times with $0.1 \mathrm{M}$ phosphate buffer solution and moved out for 12 hours. Samples were put in osmium tetroxide in $1 \%$ phosphate buffer solution $0.1 \mathrm{M}$ for 60 minutes at $4^{\circ} \mathrm{C}$. Femur were cleansed three times in bi-distillated water and dipped in $1 \%$ tannic acid solution at $4{ }^{\circ} \mathrm{C}$. Samples were dehydrated with ethanol in ascending concentrations. Then the samples were dried in SPI supplies, critical point drying machine using liquid $\mathrm{CO}_{2}$. The samples were launched on aluminum stumps, coated by gold in a SPI-ModuleTM Vac / splutter ${ }^{[24]}$. Then specimens were imaged using JEOL, JSM-52500 LV scanning electron microscope, Japan at Faculty of Medicine, Tanta University, Tanta, Egypt

The histomorphometric parameters were carried out by Image Analyzer (Leica Q 500 MC program; Leica GMBH Germany) in the Histology Department, Faculty of Medicine, Menoufia University measuring Cortical bone thickness, Osteoblast number and Osteoclast number. 10 high power fields (HPF) in each specimen were assessed.

\section{Statistical Analysis}

Data have been configurated applying descriptive statistics. These were dispensed as mean \pm standard deviation and being discrepant using Student's t-test. Significance was set at $P$ value of less than 0.05 for all contrasts. All statistical analyses were discharged with the aid of SPSS 15 (Chicago, Illinois, USA) statistical analysis software.

\section{RESULTS}

The animals of all groups were in good general condition and had normal activity and apatite compared to control group except the glucocorticoids treated group (IV) showed decreased activity. No mortality was detected in animals.

\section{Histological and Histochemical Results}

\section{Group I (control group)}

Haematoxylin and Eosin stained sections of the femur of control group displayed cortical bone covered by an outer fibrous periosteal layer (Figure 1). An inner layer of osteogenic cells called endosteum was lining the inner surface of the bone and the bone marrow cavity, formed of osteoblasts (Figure 2). Under the periosteum there were the outer circumferential lamellae (Figure 1) and around the endosteum there were the inner circumferential lamellae (Figure 2). Haversian system was formed of central canal (haversian canal) surrounded by concentric lamellae. Lacunae containing osteocytes could be distinguished between lamellae (Figures 1,2). Interstitial lamellae consisting of irregularly arranged lamellae and osteocytes were also seen (Figure 3). Normal trabecular bone architecture of interconnected bony trabuculae surrounding bone marrow cavities was observed (Figure 4).

Mallory trichrome stain showed closely packed regularly arranged bundles of collagen fibers within the bone matrix, and normal periosteal thickness. Lacunae containing osteocytes were of normal size and distribution (Figure 5)

Caspase -3 stained section showed a negative reaction to caspase -3 (Figure 6).

Osteopontin stain revealed showed normal osteopontin protein expression in the bone matrix around the lacunae (Figure 7). 


\section{Electron Microscopic Results}

Scanning electron micrographs of longitudinal sections of the femur of control group showed apparently normal cortical bone thickness formed of solid compact bone covered by outer fibrous periosteum with Sharpey's fibers. Haversian canals surrounded by osteocyte lacunae were also observed (Figure 8). Branching and anastomosing bone trabeculae of apparently uniform thickness and bone marrow cavities were also noticed (Figure 9).

\section{Group II (lepidium sativum-treated group)}

Light and scanning electron microscopic evaluation of group II declared no visible dissimilarity from the control group.

\section{Group III (teriparatide treated-group)}

Light and scanning electron microscopic evaluation of group III declared no detectable dissimilarity from the control group.

\section{Group IV (glucocorticoids treated group)}

Haematoxylin and Eosin sections of the shaft of the femur of glucocorticoids treated group showed thickened outer fibrous periosteum with apparently decreased and irregular cortical bone thickness (Figure 10). Irregular basophilic areas were seen inside acidophilic bone matrix. Large bony tunnels as well as osteoporotic cavities were observed within cortical bone (Figure 11). Osteoclasts with multiple nuclei and acidophilic cytoplasm were noticed laying on the bone surface within Howships lacunae with marked irregularity of the surface of the bone (Figure 12). Trabecular bone appeared as thin and discontinuous bony ossicles. Bone matrix appeared non homogenous with basophilic areas inside the acidophilic matrix. Areas devoid of osteocytes were also noticed (Figure 13)

Mallory trichrome staining showed apparently few irregularly arranged collagen fibers within the bone matrix and multiple osteoporotic cavities (Figure 14).

Caspase -3 staining demonstrated strong positive reaction to caspase 3 in the cytoplasm of osteocytes (Figure 15).

Osteopontin- staining demonstrated an apparent marked decrease in osteopontin expression in the bone matrix in this group (Figure 16).

Electron microscopic results revealed thinning in the cortical bone compared to control group with appearance of multiple osteoporotic cavities and marked irregularity of the outer cortical surface (Figure 17). Bone trabeculae were also thin, irregular or fractured (Figure 18).

\section{Group V (glucocorticoids and teriparatide treated- group)}

Haematoxylin and Eosin showed thickened fibrous periosteum with underlying irregular bone surface, sub-periosteal bone deposition and irregular basophilic cement line (Figure 19). Osteoclast was seen in Howships lacuna having multiple nuclei and acidophilic cytoplasm. Osteoblasts were also noticed lining the bone surface (Figure 19). Basophilic lines were observed indicating new bone formation with irregularly arranged lamellae (Figure 20). Increase in trabecular area compared to glucocorticoids treated group and faintly stained areas in bone trabeculae were also noticed (Figure 21).

Mallory trichrome stain showed newly formed irregularly arranged bone lamellae with irregularly arranged collagen fibers. Thickened periosteum and irregular bony surface were also noticed (Figure 22). Collagen fibers were apparently increased within the bone matrix with eakly stained faint blue areas. Still there were erosion cavities (Figure 22).

Caspase -3 showed negative immune raction to caspase -3 , with areas of positive reaction in inner cellular periosteal layer (Figure 23).

Osteopontin showed positive osteopontin protein expression in the bone matrix (Figure 24).

Electron microscopic results revealed cortical compact bone with some extending bone trabeculae. Irregular cortical bone thickness with more or less regular and continuous bone trabeculae were observed (Figure 25).

\section{GroupVI (glucocorticoids and lepidium sativum- treated group)}

Haematoxylin and Eosin stain of this group showed normal cortical bone covered by normal periosteum, with underlying regularly arranged external circumferential lamellae and basophilic cement line (Figure 26).

Plenty of osteoblasts were seen lining the bone marrow cavities. Osteocytes in their lacunae were of normal shape and distribution. Normal bone trabeculae with normal bone marrow cavities were observed (Figure 27).

Mallory trichrome stain showed regularly arranged densely packed collagen fibers. The periosteal thickness appeared normal (Figure 28).

Caspase -3 were similar to control group and showed a negative immune reaction to caspase -3 (Figure 29).

Osteopontin showed strong positive osteopontin protein expression in the bone matrix (Figure 30).

Electron microscopic results revealed apparently normal cortical and periosteal thickness containing osteocyte lacunae and haversian canals (Figure 31). Regular continuous bone trabeculae of normal thickness were also observed (Figure 32). Bone marrow cavities were seen.

\section{Biochemical Results}

Serum Calcium Level

Statistical analysis indicated a significant decrease in serum calcium level in glucocorticoids treated group 
(group V) compared to control group. While there was no notable change in teriparatide and glucocorticoids treated group (group V) and glucocorticoids and lepidium sativum treated group (group VI) compared to control group. No significant difference was pronounced between group $\mathrm{V}$ and VI. All the above statistical data were summarized in (Table 1, Diagram 1)

\section{Serum alkaline Phosphatase Level}

Glucocorticoids treated group (group IV) as well as glucocorticoids and teriparatide treated group (group V) showed highly significant increase ( $p$ value $<0.01$ ) compared with control group. While glucocorticoids and lepidium sativum group (group VI) did not exhibit any significant change compared to the control group. All the above statistical data were summarized in (Table 2 and Diagram 2).

\section{Quantitative Study}

\section{Cortical Thickness}

The glucocorticoids treated group (group IV) showed highly significant decrease in cortical thickness ( $p$ value $<0.01$ ). In glucocorticoids and teriparatide treated group (group V) the $P$ value was $<0.05$ indicating a significant decrease in cortical thickness in this group compared to control group. In contrast, the mean cortical thickness of glucocorticoids and lepidium sativum group (group VI) showed non- remarkable change with the control group ( $p$ value $>0.05$ ). Comparing glucocorticoids and teriparatide treated group (group V) to glucocorticoids and lepidium sativum treated group (group VI) $p$ value was $<0.05$ indicating a significant increase in the group VI. All the above statistical data were summarized in (Table 3, Diagram 3)

\section{Cortical Bone Osteoblast Number}

Compared to the control (group I) animals, the mean number of osteoblast revealed a highly significant decrease in osteoblast number in glucocorticoids treated group (group IV) and a significant decrease in glucocorticoids and teriparatide treated group (group V). Glucocorticoids and lepidium sativum treated group (group VI) showed non-significant change. Comparing glucocorticoids and teriparatide treated group (group V) with glucocorticoids and lepidium sativum treated group (group VI) $P$ value was $<0.05$ indicating a significant increase in osteoblast number in group VI animals. All the above statistical data were summarized in (Table 4 , Diagram 4 )

\section{Osteoclast Number}

The mean osteoclast number in glucocorticoids treated group (group IV) was significantly increased compared to control group. Noticeable significant reduction in the number of osteoclasts in glucocorticoids and lepidium sativum treated group (group VI) compared with glucocorticoids and teriparatide treated group (group V). All the above statistical data were summarized in (Table 5, Diagram 5)

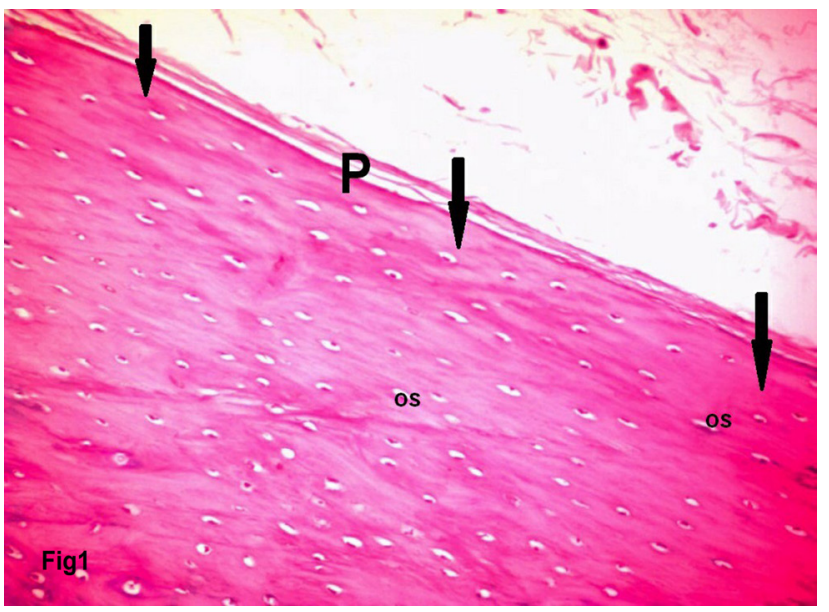

Fig. 1: Longitudinal section of shaft of guinea pig femur of control group showing periosteum (p) covering the external surface of the bone, beneath it there are external circumferential lamellae (arrows) running parallel to the outer circumference of the bone. Osteocytes (OS) in lacunae could be noticed in the bone matrix. $(\mathrm{H} \& \mathrm{E} \times 200)$

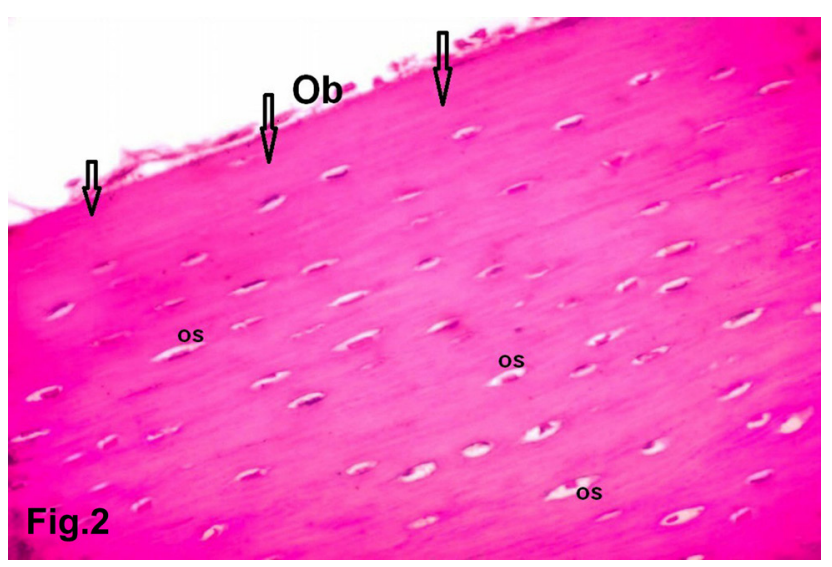

Fig. 2: Longitudinal section of shaft of guinea pig femur of control group showing osteoblasts $(\mathrm{Ob})$ forming endosteal layer, surrounded by regularly arranged internal circumferential lamellae (arrows). Osteocytes (OS) in lacunae could be noticed in the bone matrix. $(\mathrm{H} \& \mathrm{E} \times 200)$

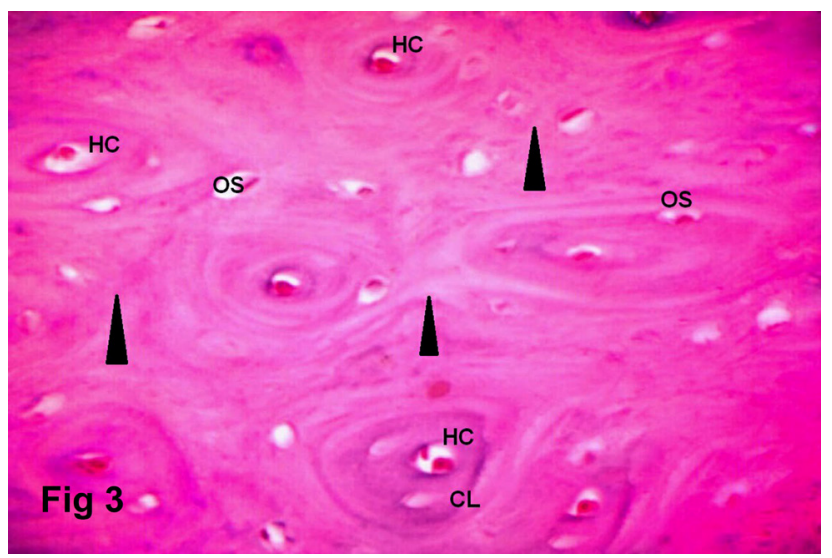

Fig. 3: Ttransverse section of shaft of guinea pig femur of control group showing haversian system (osteon) consisting of haversian canals (HC) surrounded by concentric lamellae. In between lamellae, normal osteocytes (OS) appear within their lacunae. Basophilic cement line is seen in few osteons (CL). Notice the presence of interstitial lamellae inbetween the osteons (arrow head). (H\&E×400) 


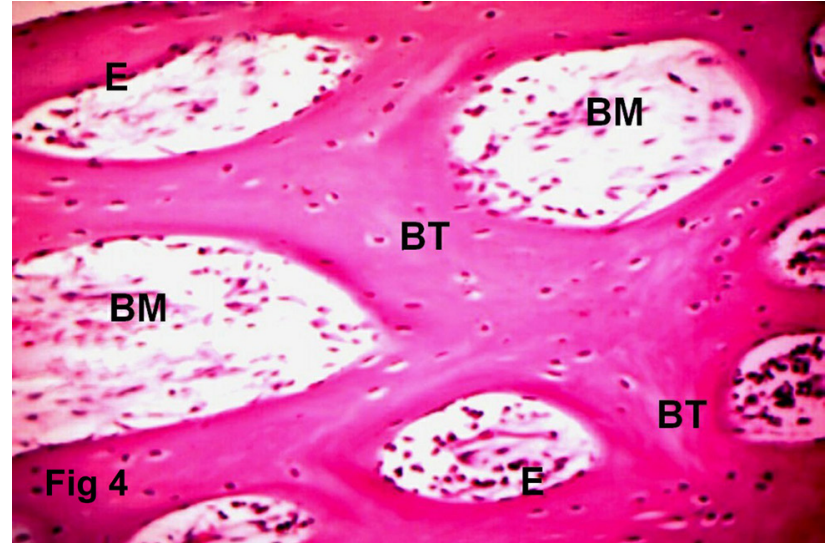

Fig. 4: Longitudinal section of the head of guinea pig femur of control group showing normal architecture of trabecular bone formed of interconnected bony trabeculae (BT) surrounding bone marrow cavities (BM) lined by endosteum (E). $(\mathrm{H} \& \mathrm{E} \times 200)$

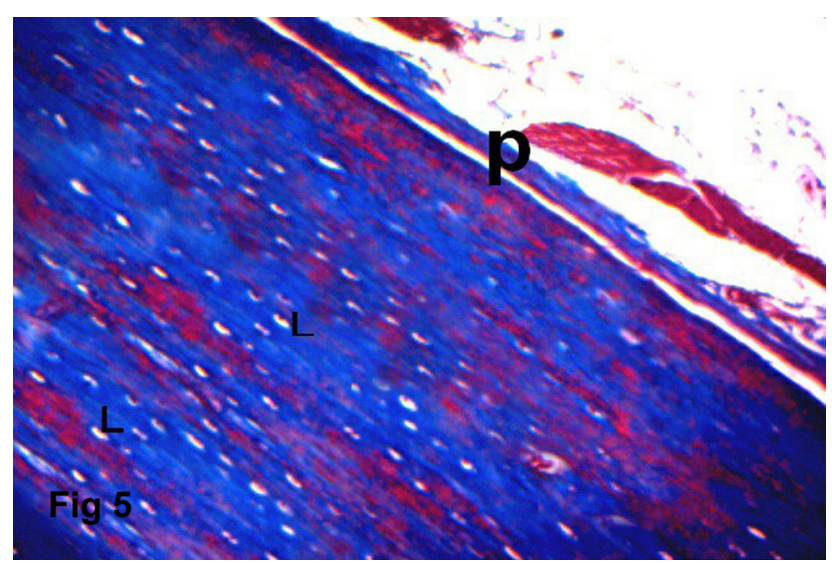

Fig. 5: Longitudinal section of shaft of guinea pig femur of control group showing closely packed regularly arranged bundles of collagen fibers (blue color) within the reddish bone matrix, and apparently normal periosteal thickness (P). Lacunae containing osteocytes (L) are of normal shape and distribution. (Mallory trichrome $\times 200$ )

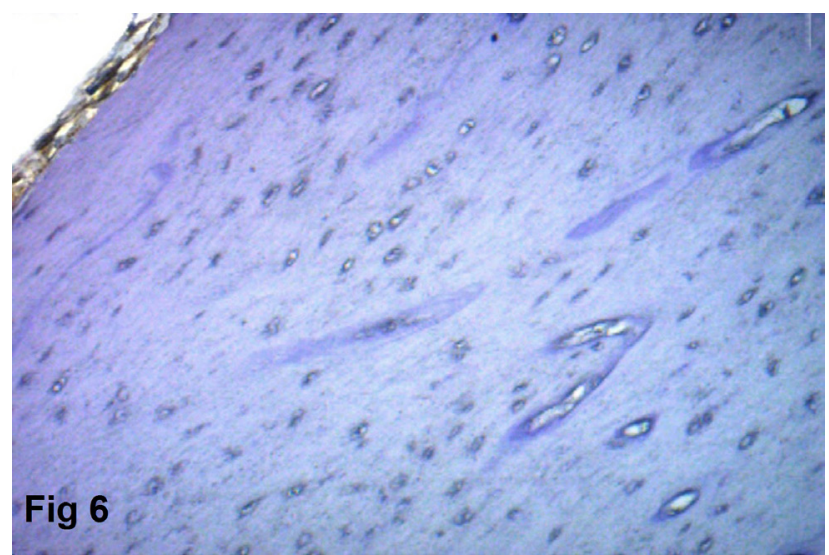

Fig. 6: Longitudinal section of shaft of guinea pig femur of control group demonstrated negative immune response to caspase-3. (PAP $\times 200)$

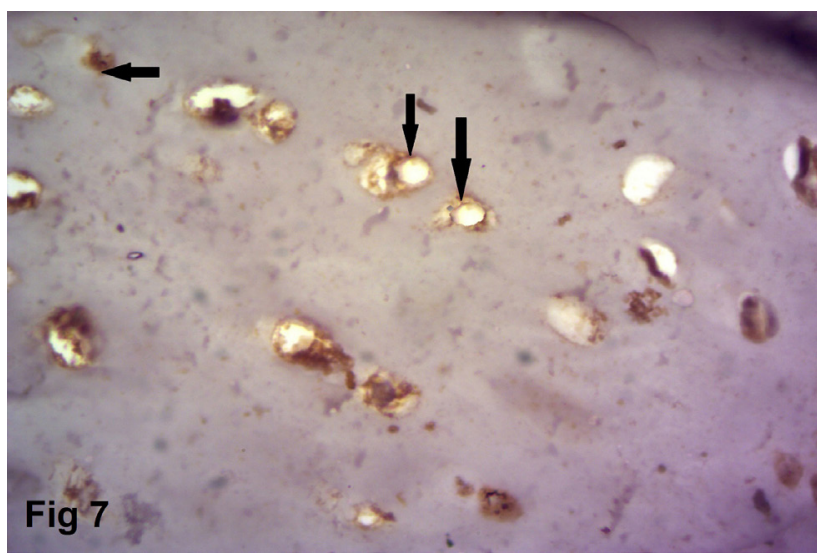

Fig. 7: Longitudinal section of shaft of guinea pig femur of control group showing normal expression of osteopontin protein in the bone matrix around the lacunae (arrows) $(\mathrm{PAP} \times 1000)$

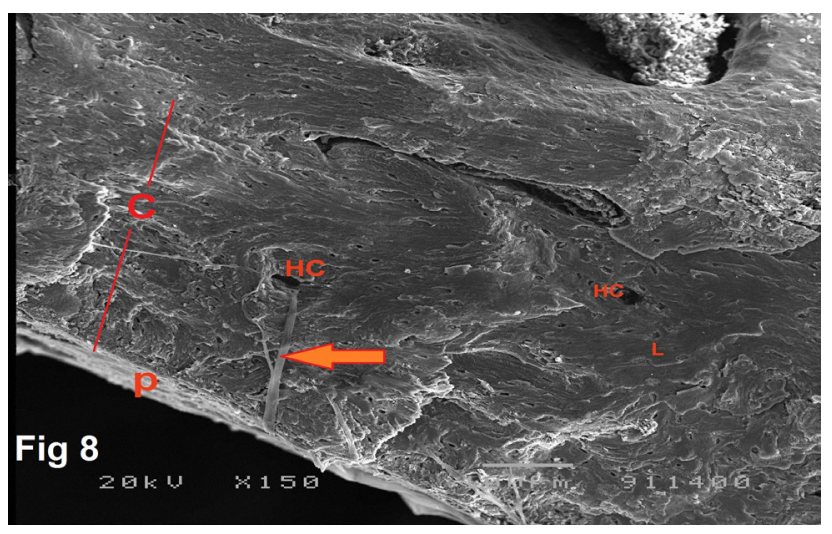

Fig. 8: A scanning electron micrograph of a longitudinal section of guinea pig femur of control group showing apparently normal thickness cortical bone $(\mathrm{C})$, covered by outer fibrous periosteum $(\mathrm{P})$. There are also haversian canals (HC) surrounded by osteocyte launea (L). Notice the presence of sharpy fibers (arrow)

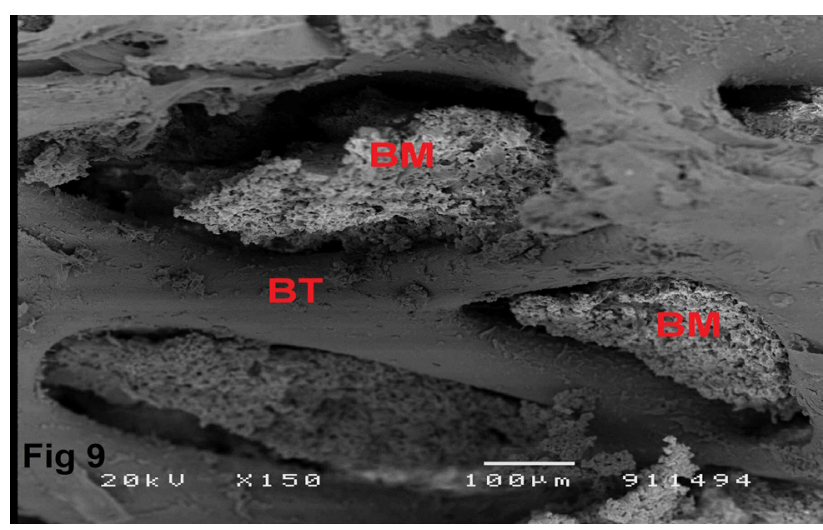

Fig. 9: A scanning electron micrograph of a longitudinal section of guinea pig femur of control group showing branching and anastomosing bone trabeculae of uniform apparently normal thickness (BT), with presence of bone marrow in-between (BM) 


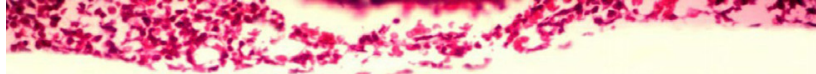

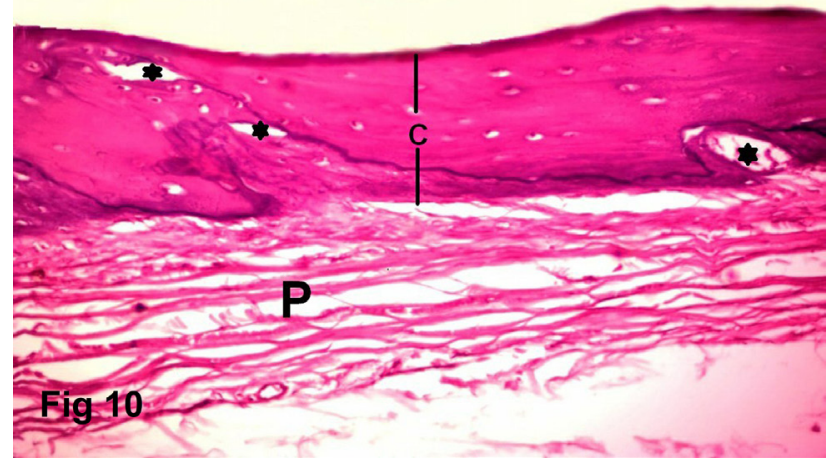

Fig. 10: Longitudinal section of the shaft of guinea pig femur of glucocorticoids treated group revealed apparent decrease in the thickness of the cortical bone (C) with appearance of osteoporotic cavities $(*)$. The fibrous periosteum is markedly thickened $(\mathrm{P})$. $(\mathrm{H} \& \mathrm{E} \times 200)$

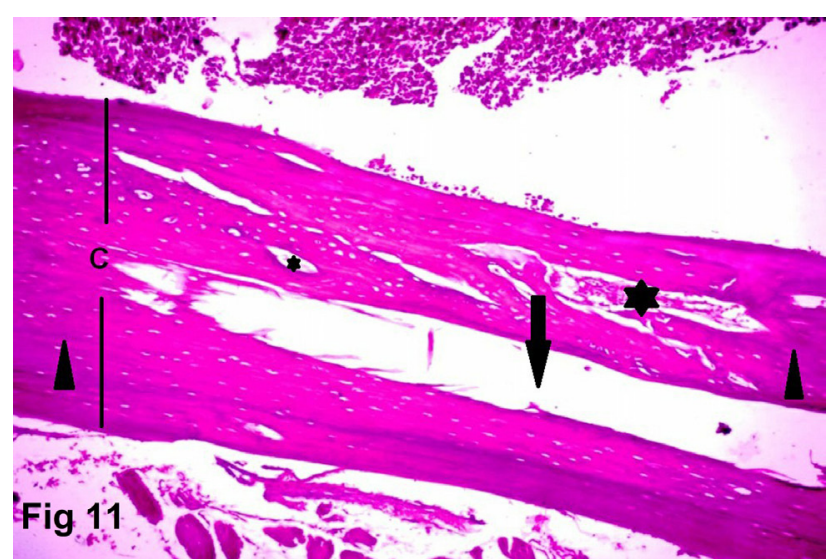

Fig. 11: Longitudinal section of the shaft of guinea pig femur of glucocorticoids treated group showing irregular thickness of cortical bone (C) with appearance of large bony tunnel (arrow) and multiple osteoporotic cavities $(*)$. Irregular basophilic areas (arrow head) inside acidophilic bone matrix are notice $(\mathrm{H} \& \mathrm{E} \times 100)$

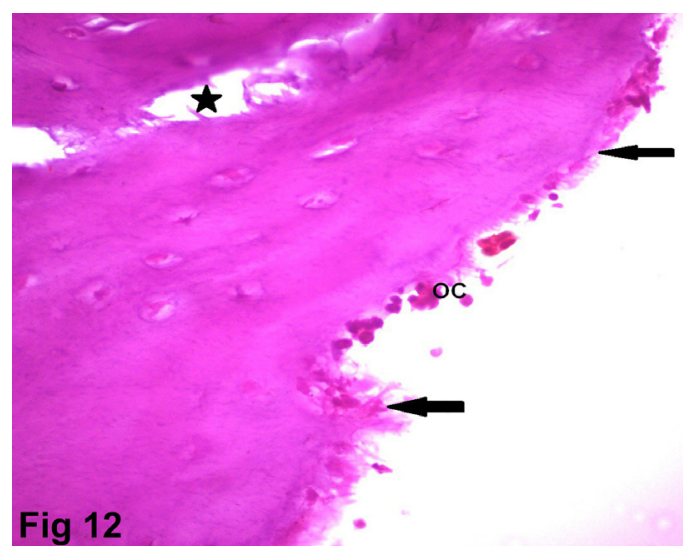

Fig. 12: Longitudinal section of the shaft of guinea pig femur of glucocorticoids treated group showing osteoclasts $(\mathrm{OC})$ with multiple nuclei and acidophilic cytoplasm laying on the bone surface within howships lacunae. Notice the presence of osteoporotic cavities $(*)$ and marked irregularity of the surface of the bone (arrow). (H\&E×400)

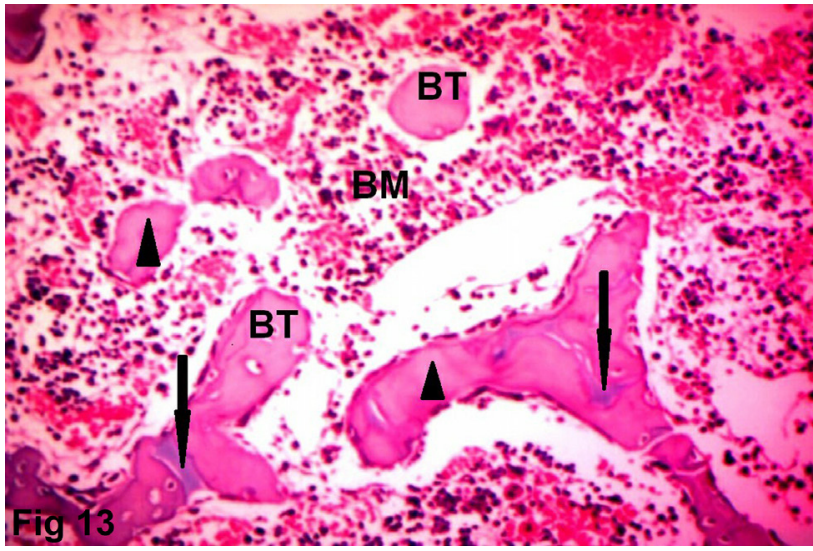

Fig. 13: Longitudinal section of the head of guinea pig femur of glucocorticoids treated group showing loss of continuity of the bone trabeculae appearing as discontinuous bony ossicles (BT) with bone marrow in-between (BM) .Bone matrix appears non homogenous with basophilic areas (arrow) inside the acidophilic matrix. There are also areas devoid of osteocytes (arrow head). (H\&E×200)

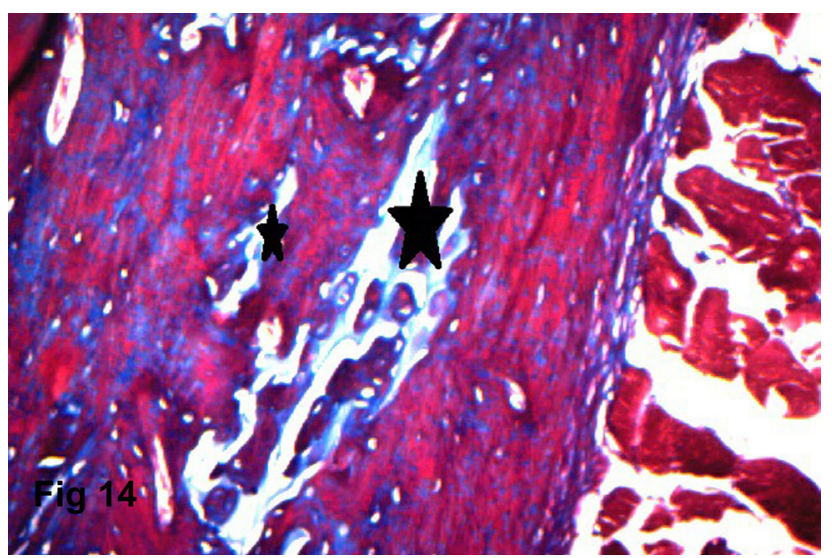

Fig. 14: Longitudinal section of the shaft of guinea pig femur of glucocorticoids treated group showing irregularly arranged apparently few collagen fibers (Blue color), within the bone matrix (red color), There are also multiple osteoporotic cavities $(*)$. (Mallory trichrome $\times 200$ )

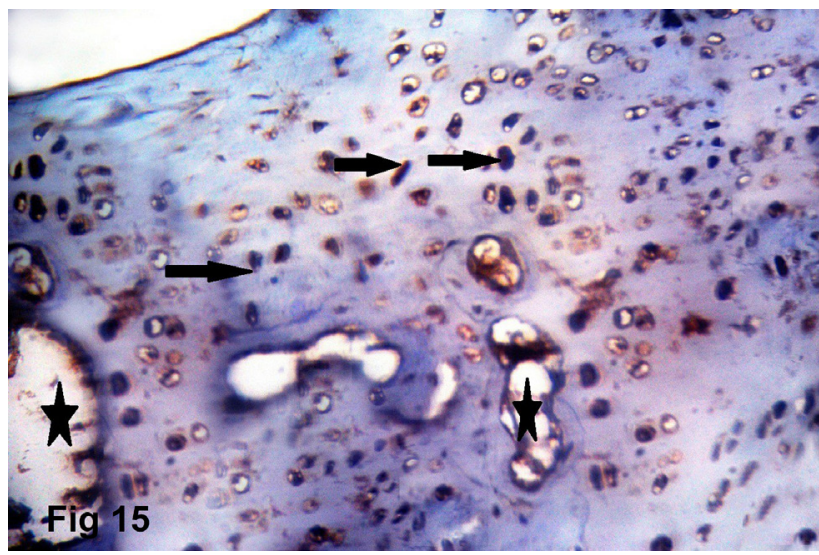

Fig. 15: Longitudinal section of the shaft of guinea pig femur of glucocorticoids treated group showing strong positive cytoplasmic reaction of the osteocytes to caspase-3(arrow). Notice the presence of osteoporotic cavities $(*)(\mathrm{PAP} \times 200)$ 


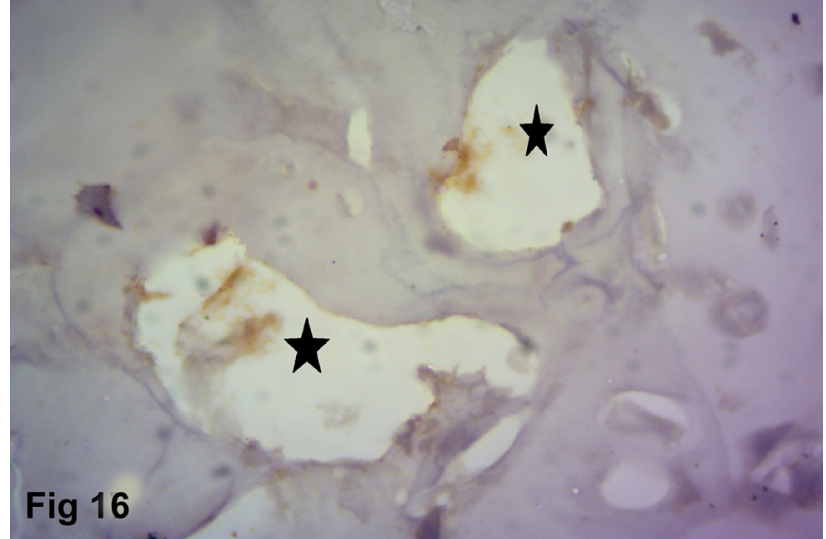

Fig. 16: Longitudinal section of the shaft of guinea pig femur of glucocorticoids treated group showing an apparent marked decrease in osteopontin expression in the bone matrix. Notice the presence of osteoporotic cavities $(*)(\mathrm{PAP} \times 1000)$

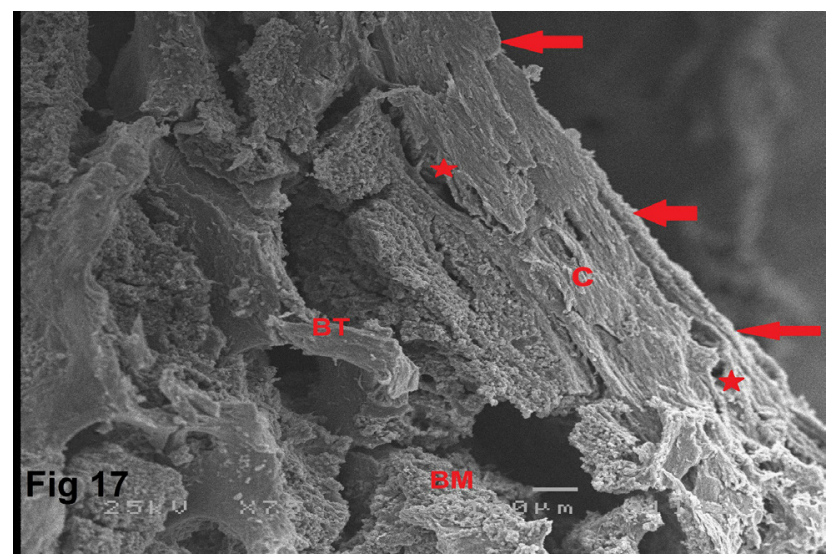

Fig. 17: A scanning electron micrograph of a longitudinal section of guinea pig femur of glucocorticoids treated group showing thinning in the cortical bone compared to control group (C) with appearance of multiple osteoporotic cavities (*) and marked irregularity of the outer cortical surface (arrow). Bone trabeculae are also thin and discontinuous (BT). Bone marrow is seen in cavities (BM)

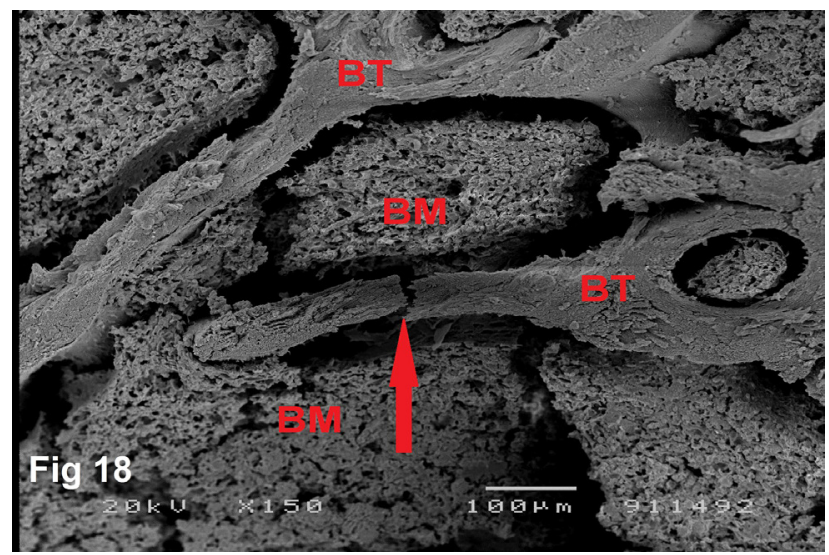

Fig. 18: A scanning electron micrograph of a longitudinal section of guinea pig femur of glucocorticoids treated group showing apparently thin irregular bone trabeculae (BT), one of them is fractured (arrow). Bone marrow is seen in cavities (BM).

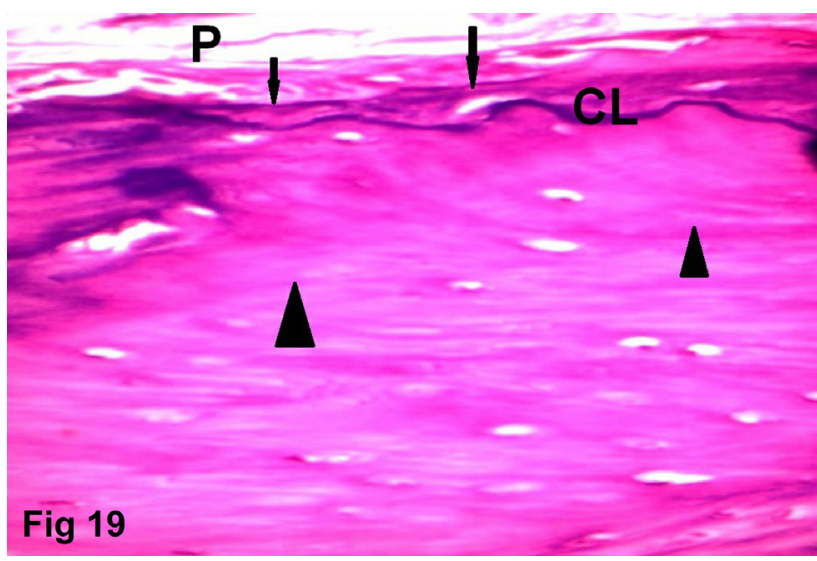

Fig. 19: Longitudinal section of the shaft of guinea pig femur of glucocorticoids and teriparatide - treated group thickened fibrous periosteum $(\mathrm{P})$ with underlying irregular bone surface (arrow) and sub periosteal bone deposition with irregular basophilic cement line (CL). Areas of bone matrix that devoid of osteocytes are still noticed (arrow head). (H\&E $\times 200)$

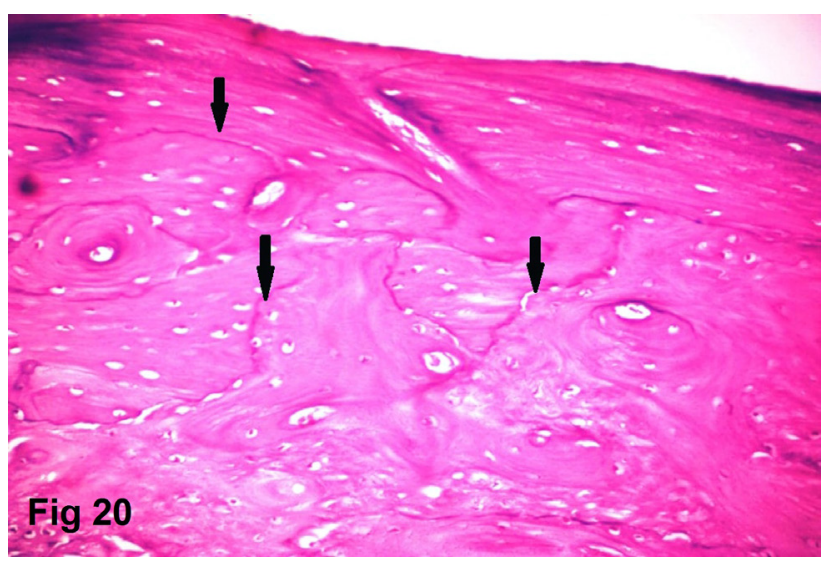

Fig. 20: Transverse section of the shaft of guinea pig femur of glucocorticoids and teriparatide - treated group showing basophilic lines indicating new bone formation with irregularly arranged bone lamellae (arrows). (H\&E×200)

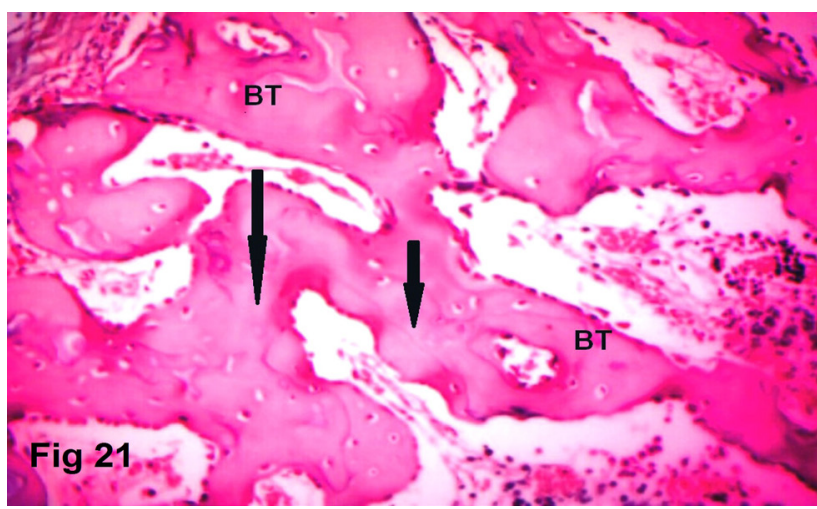

Fig. 21: Longitudinal section of the head of guinea pig femur of glucocorticoids and teriparatide - treated group showing noticeable increase in trabecular area (BT) compared to glucocorticoids treated group. Faintly stained areas are noticed within the bone trabeculae (arrow). (H\&E×200) 


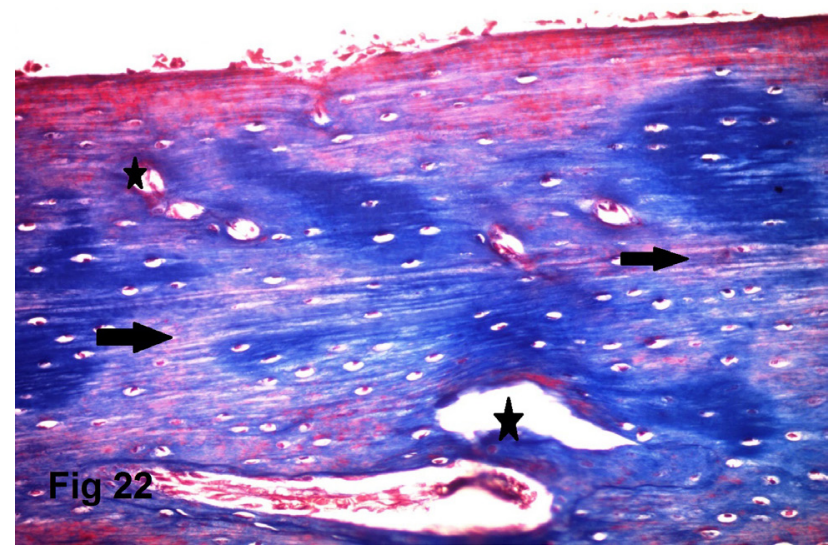

Fig. 22: Longitudinal section of the shaft of guinea pig femur of glucocorticoids and teriparatide - treated group showing increase in collagen fibers within the matrix (blue color) with weakly stained faint blue areas ( arrow ). Still there are erosion cavities in the matrix (*). (Mallory trichrome $\times 200$ )

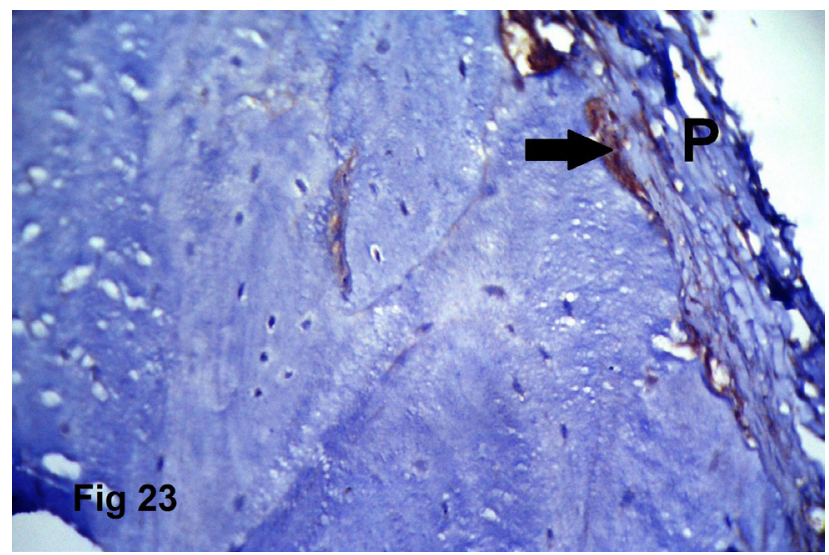

Fig. 23: Longitudinal section of the shaft of guinea pig femur of glucocorticoids and teriparatide - treated group showing negative immune rection to caspase-3. Notice the apparently thickened periosteum $(\mathrm{P})$. Inner cellular layer of periosteum shows small areas of positive reaction (arrow) $(\mathrm{PAP} \times 400)$

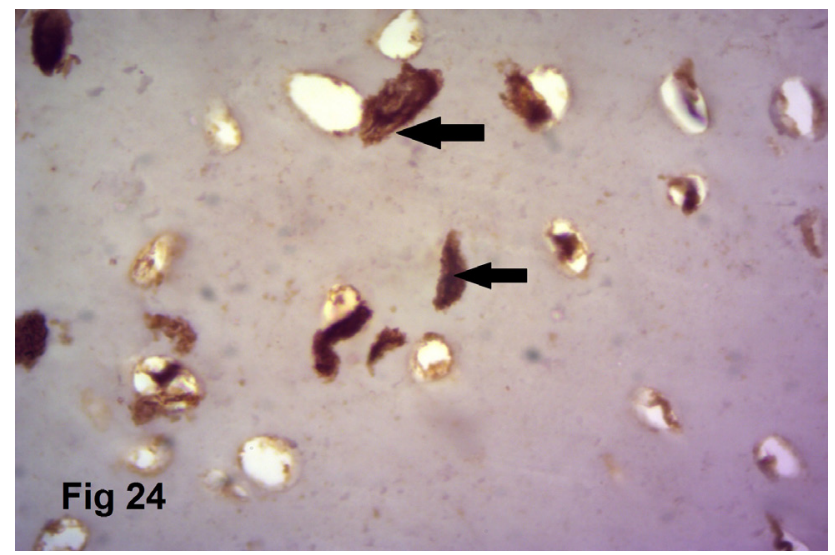

Fig. 24: Longitudinal section of the shaft of guinea pig femur of glucocorticoids and teriparatide - treated group showing positive osteopontin protein expression in the bone matrix (arrow). ( PAP $\times 1000)$

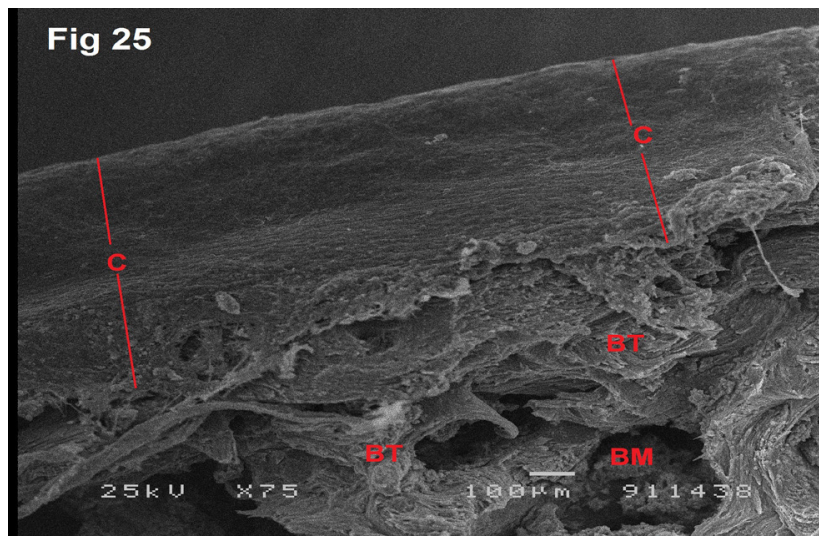

Fig. 25: A scanning electron micrograph of a longitudinal section of guinea pig femur of glucocorticoids and teriparatide- treated group showing cortex (C) formed of solid compact bone with some extending bone trabeculae. Irregular cortical bone thickness, bone trabeculae (BT) are also noticed. Bone marrow is seen in cavities (BM)

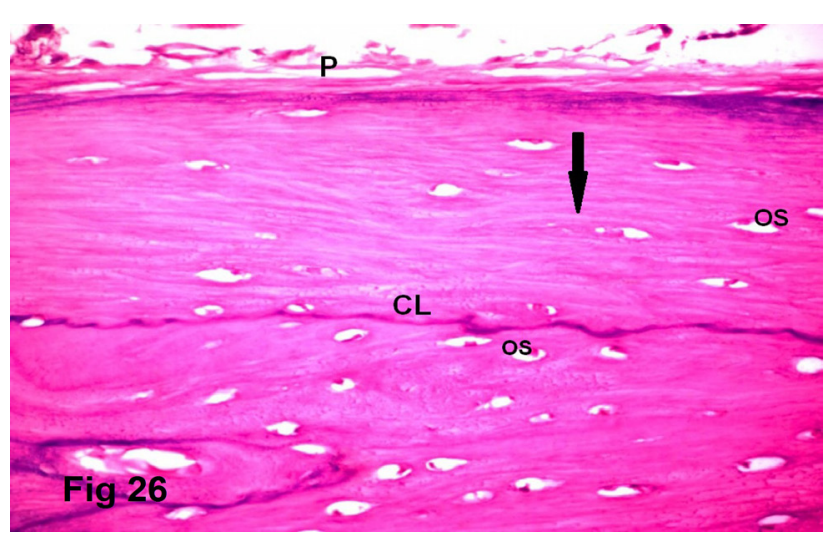

Fig. 26: Longitudinal section of the shaft of guinea pig femur of glucocorticoids and lepidium sativum - treated group showing apparently normal periosteal thickness (P) with underlying regularly arranged external circumferential lamellae (arrow) and basophilic cement line (CL). Notice ,osteocytes are of normal shape and distribution (OS). $(\mathrm{H} \& \mathrm{E} \times 200)$

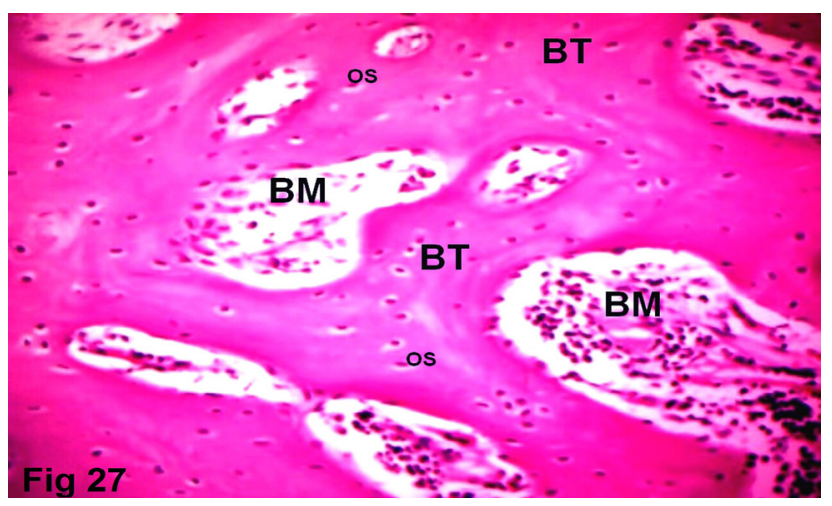

Fig. 27: Longitudinal section of the head of guinea pig femur of glucocorticoids and lepidium sativum treated group showing inteconnected bone trabeculae (BT) surrounding bone marrow cavities (BM), osteocytes (OS) in their lacunae are of normal shape and distribution. $(\mathrm{H} \& \mathrm{E} \times 200)$ 


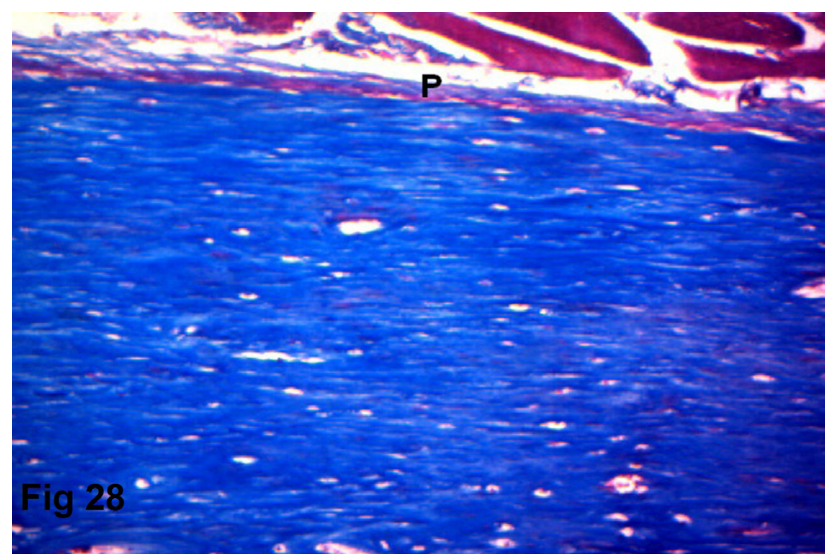

Fig. 28: Longitudinal section of the shaft of guinea pig femur of glucocorticoids and lepidium sativum - treated group showing regularly arranged densely packed collagen fibers (blue color). The periosteal thickness appears apparently normal (P). (Mallory trichrome $\times 200$ )

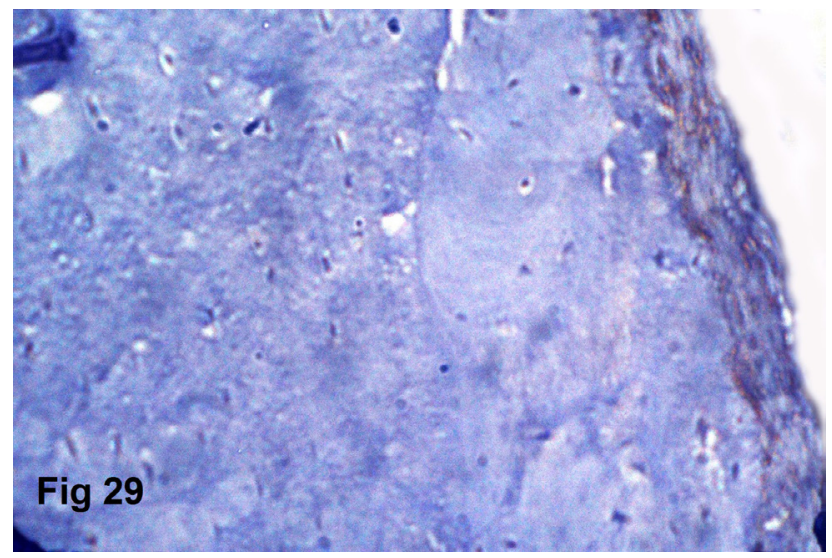

Fig. 29: Longitudinal section of the shaft of guinea pig femur of glucocorticoids and lepidium sativum - treated group showing negative immune rection to caspase-3. ( $\mathrm{PAP} \times 400)$

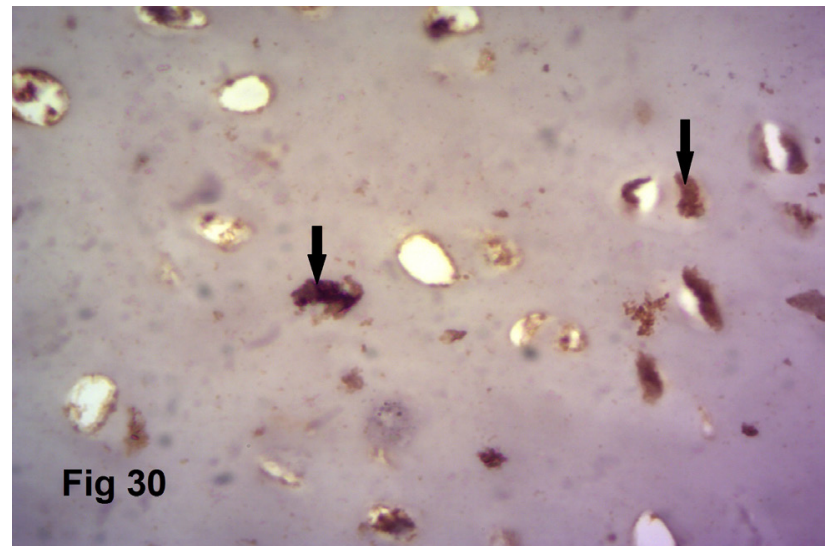

Fig. 30: Longitudinal section of the shaft of guinea pig femur of glucocorticoids and lepidium sativum - treated group showing strong positive osteopontin protein expression in the bone matrix (arrow). (PAP $\mathrm{X} 1000)$

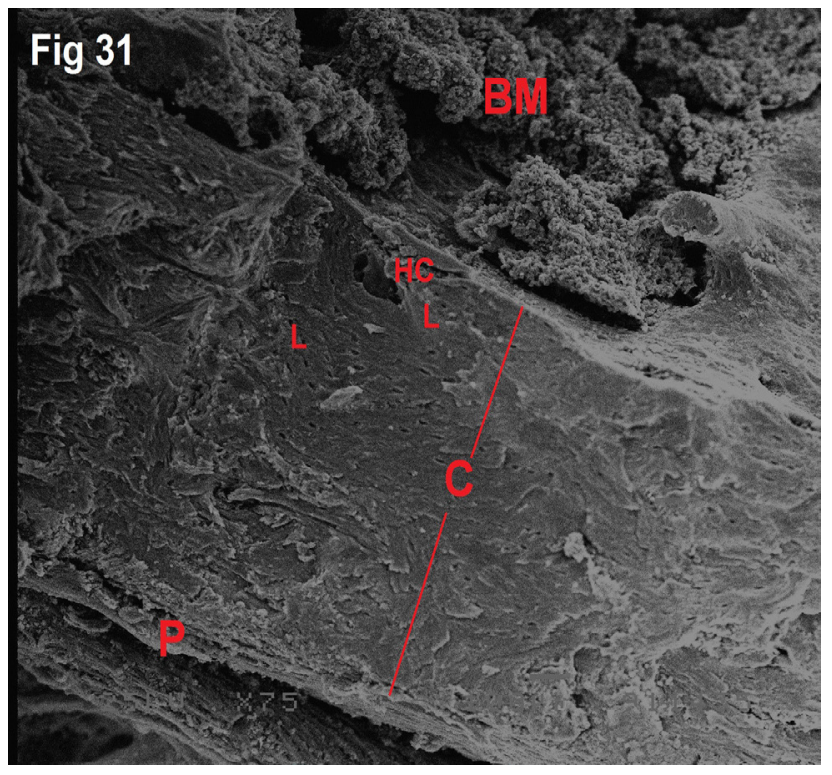

Fig. 31: A scanning electron micrograph of a longitudinal section of guinea pig femur of glucocorticoids and lepidium sativum- treated group showing apparently normal cortical ( C) and periosteal (P) thickness compared to control group, the cortex contains osteocyte lacunae (L). Haversian canal is also noticed (HC). Bone marrow is seen in cavities (BM)

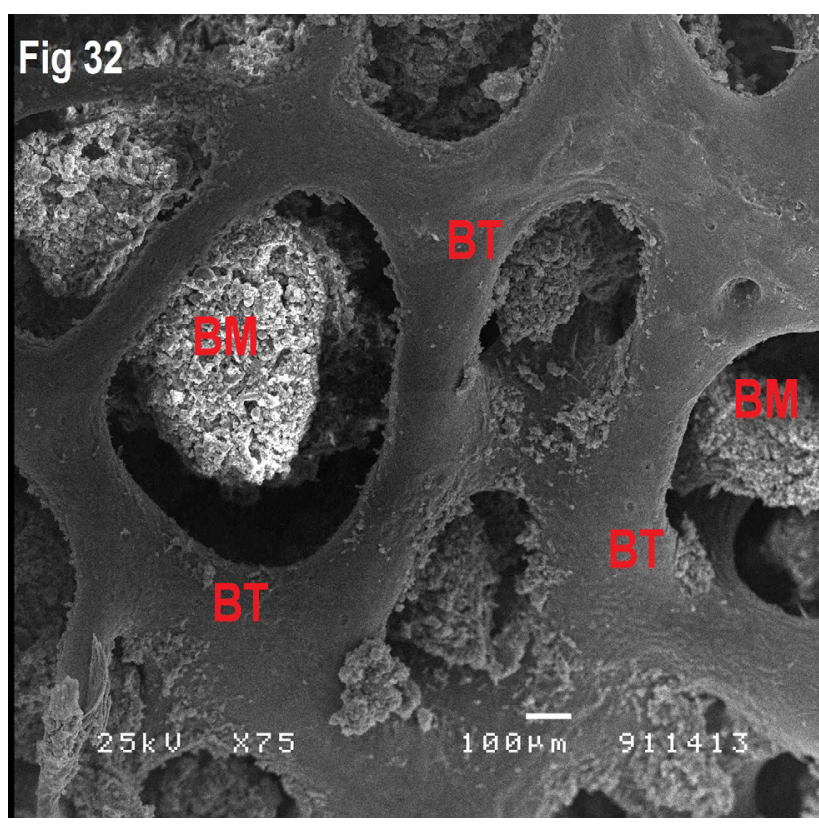

Fig. 32: A scanning electron micrograph of a longitudinal section of guinea pig femur of glucocorticoids and lepidium sativum treated- group showing regular continuous normal thickness bone trabeculae (BT) compared to control group. Bone marrow is seen in cavities (BM) 
Table 1: Mean serum calcium level $(\mathrm{mg} / \mathrm{dl})$ in control and treated groups and $\mathrm{P}$ value between different groups

\begin{tabular}{lccl}
\hline & Mean \pm SD & t-test & $p$ value \\
\hline group I & $9.51 \pm 0.74$ & ---------- & \\
group II & $9.28 \pm 0.8$ & 2.5 & $>0.05$ \\
group III & $10.19 \pm 0.59$ & 0.45 & $>0.05$ \\
group IV & $8.48 \pm 1.15$ & 2.63 & $<0.05$ \\
group V & $10.08 \pm 0.49$ & 2.25 & $>0.05$ \\
group VI & $9.46 \pm 0.72$ & 0.17 & $>0.05$ \\
group V-VI & -------- & 2.49 & $>0.05$ \\
\hline$P$ value $>0.05$ non-significant & &
\end{tabular}

$P$ value $>0.05$ non-significant

$P$ value $<0.05$ significant

$P$ value $<0.01$ highly significant

Table 2: The mean serum alkaline phosphatase level (U/l) in control and treated groups and $\mathrm{P}$ value between different groups

\begin{tabular}{lccc}
\hline & Mean \pm SD & t-test & p value \\
\hline group I & $49.92 \pm 13.14$ & ---- & \\
group II & $62.17 \pm 17.86$ & 1.76 & $>0.05$ \\
group III & $46.08 \pm 13.49$ & 0.7 & $>0.05$ \\
group IV & $145.83 \pm 32.46$ & 7.49 & $<0.01$ \\
group V & $85 \pm 16.56$ & 5.75 & $<0.01$ \\
group VI & $57.5 \pm 11.12$ & 1.53 & $>0.05$ \\
group V-VI & ------- & 4.78 & $<0.01$ \\
\hline$P$ value $>0.05$ non-significant & &
\end{tabular}

$P$ value $<0.05$ significant

$P$ value $<0.01$ highly significant

Table 3: Mean cortical thickness (micrometer) in control and treated groups

\begin{tabular}{lccl}
\hline & Mean \pm SD & t-test & $p$ value \\
\hline group I & $680.4 \pm 41.28$ & ----- & \\
group II & $643 \pm 32.15$ & 1.21 & $>0.05$ \\
group III & $697 \pm 32.37$ & 0.49 & $>0.05$ \\
group IV & $192 \pm 25.07$ & 13.8 & $<0.01$ \\
group V & $584.4 \pm 22.98$ & 3.8 & $<0.05$ \\
group VI & $643.6 \pm 15.81$ & 1.3 & $>0.05$ \\
group V-VI & ------- & 4.75 & $<0.05$ \\
\hline Pvalue $>0.05$ & &
\end{tabular}

$P$ value $>0.05$ non-significant

$P$ value $<0.05$ significant

$P$ value $<0.01$ highly significant

Table 4: Mean osteoblast number in control and treated groups

\begin{tabular}{lccc}
\hline & Mean \pm SD & t-test & $p$ value \\
\hline group I & $19.2 \pm 1.92$ & ----- & \\
group II & $18.8 \pm 1.92$ & 0.33 & $>0.05$ \\
group III & $19.8 \pm 2.11$ & 0.37 & $>0.05$ \\
group IV & $11.8 \pm 1.3$ & 7.12 & $<0.01$ \\
group V & $17 \pm 0.7$ & 2.4 & $<0.05$ \\
group VI & $18.8 \pm 1.3$ & 0.39 & $>0.05$ \\
group V-VI & ------ & 2.7 & $<0.05$ \\
\hline Pvalue $>0.05$ & &
\end{tabular}

$P$ value $>0.05$ non-significant

$P$ value $<0.05$ significant

$P$ value $<0.01$ highly significant
Table 5: Mean osteoclast number in control and treated groups and $P$ value between different groups

\begin{tabular}{lcc}
\hline & Mean $\pm \mathrm{SD}$ & $p$ value \\
\hline group I & $0.2 \pm 0.4$ & \\
group II & $0.00 \pm 0.00$ & $>0.05$ \\
group III & $1.1 \pm 0.7$ & $<0.05$ \\
group IV & $2.3 \pm 0.78$ & $<0.01$ \\
group V & $1.7 \pm 0.45$ & $<0.01$ \\
group VI & $0.00 \pm 0.00$ & $>0.05$ \\
group V-VI & --------- & $<0.05$ \\
\hline$P$ value $>0.05$ non-significant & \\
$P$ value $<0.05$ significant & \\
$P$ value $<0.01$ highly significant &
\end{tabular}

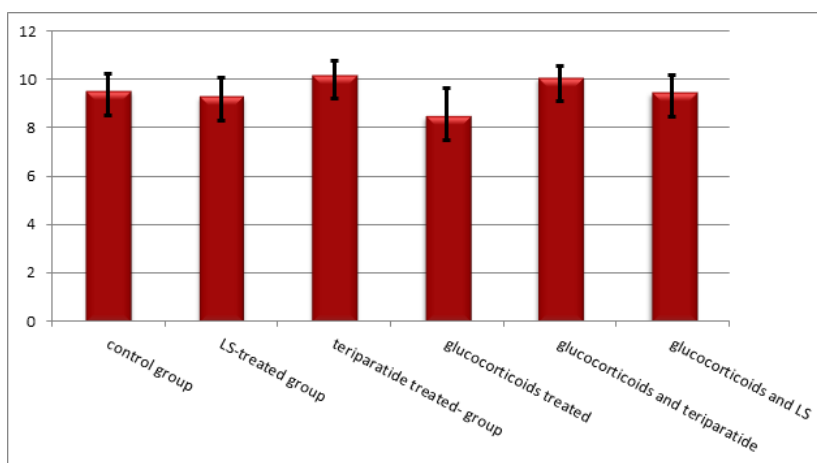

Diagram 1: Mean Serum calcium level

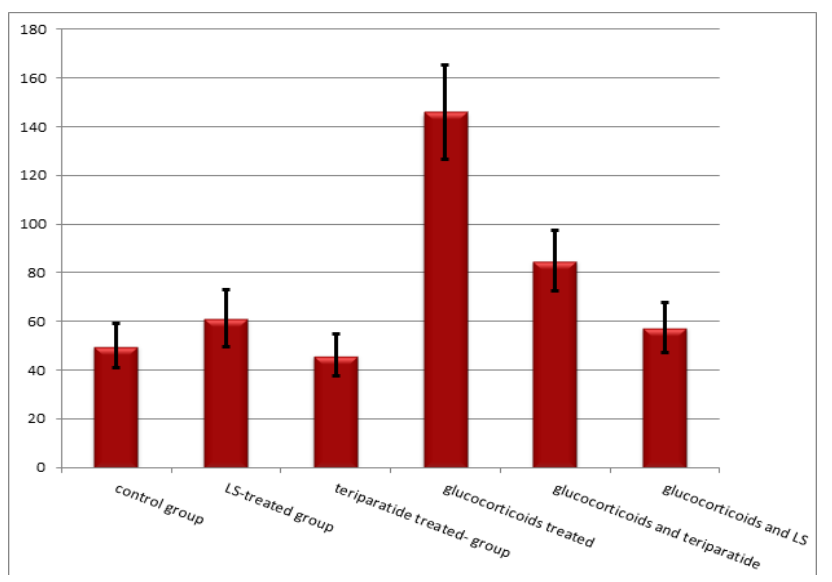

Diagram 2: The mean serum alkaline phosphatase level

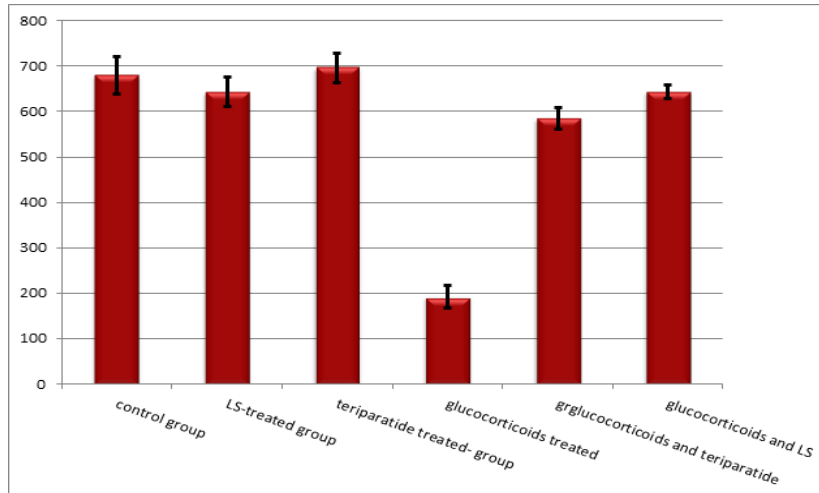

Diagram 3: Mean cortical thickness (micrometer) 


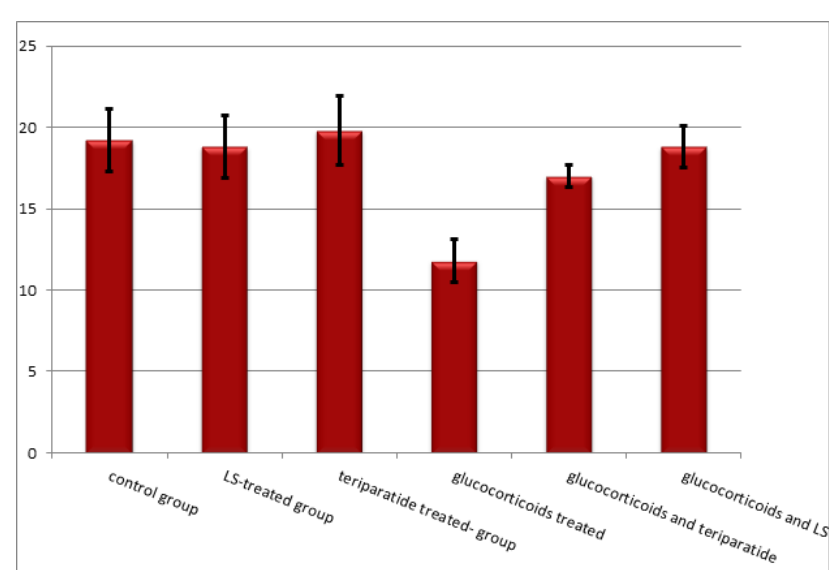

Diagram 4: Mean osteoblast number

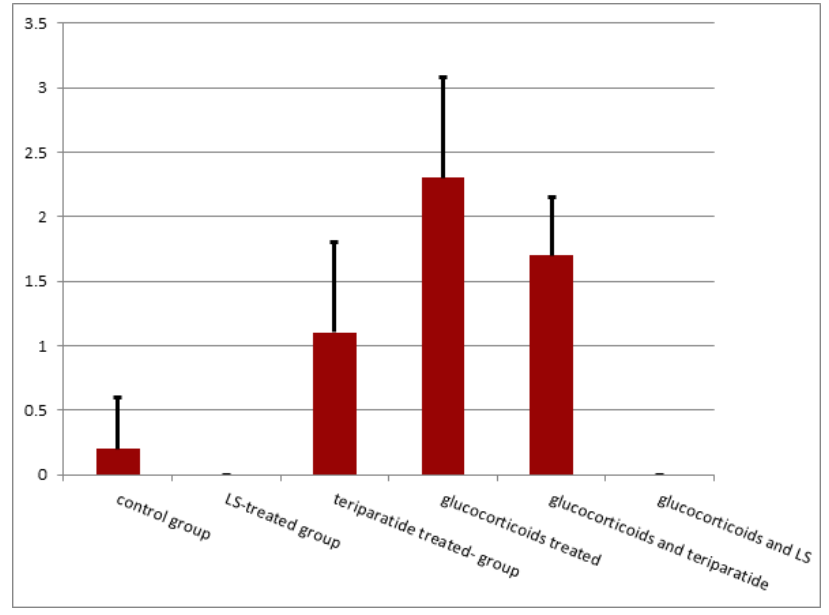

Diagram 5: Mean osteoclast number

\section{DISCUSSION}

Osteoporosis is described as a major health problem and generally specified by decrease in bone mass with greatly increased fracture risk ${ }^{[25]}$. The bone is going through continuous metamorphosis, with continual sequences of bone resorption by osteoclasts followed by formation of new bone by osteoblasts. This process secures rebuilding of recurrent fractures and restores the bony architecture ${ }^{[26]}$. Osteoporosis take place when bone depletion overreaches bone synthesis ending in lowering bone mass, declined bone microarchitecture and enhance risk of fracture ${ }^{[27,28]}$.

In this study Glucocorticoids were used as osteoporotic inducing drug $(3.5 \mathrm{mg} / \mathrm{kg} /$ day for 4 weeks) according to Hulley et al. ${ }^{[18]}$. Previous researches designated those GCs induced-osteoporosis (GIO) to take place due to instant and continual decreased in bone genesis and a fast and impermanent increase in bone resorption ${ }^{[29]}$.

Teriparatide is a part and a recombinant form of the parathyroid hormone ${ }^{[30]}$. Usage of teriparatide was selected for the current study as it has been confirmed to stimulate bone genesis through motivation of osteoblasts function and formation ${ }^{[31,32]}$. In animals, the periodic dispensing of teriparatide has a growth-promoting effect on spongy and cortical bone thus; improve bone strength ${ }^{[33]}$.

Herbal remedy has been broadly used as an alternative of chemical drugs owing to its minor adverse effects. Lepidium sativum is cultivated widely in the Middle East. It is mainly advised by ethnomedicine for treatment of hypertension, diabetes management, renal disorders and phytotherapy. Lepidium sativum seeds are popular as a conventional remedy for fracture ${ }^{[11]}$. Previous characteristics have aroused our attention to evaluate its capacity to manage osteoporosis. Lepidium Sativum (LS) in the present study was administrated in a dose of a dose $300 \mathrm{mg} / \mathrm{kg}$ daily ${ }^{[16]}$.

Researchers have evaluated the good impact of $\mathrm{L}$ sativum seeds ${ }^{[11]}$ and roots ${ }^{[14]}$ on bone strength. Despite that, there is a lack of data on the effect of Lepidium sativum on bone metabolism. Therefore, we were aiming to assess the impacts of lepidium sativum versus teriparatide on glucocorticoid-induced osteoporosis (GIO) in adult male guinea pigs.

In the current study, glucocorticoids treated group revealed thickened outer fibrous periosteum with apparently decreased and irregular cortical bone thickness, Irregular basophilic areas and bony tunnels within cortical bone. Multiple osteoclasts, marked irregularity of the surface of the bone, multiple osteoporotic cavities, and disturbed architecture of trabecular bone and decreases collagen fibers. Similar findings were reported by Shady and $\mathrm{Nooh}^{[34]}$. Saad et al. ${ }^{[35]}$ proved that this pathological finding added to the confirmation of osteoporotic bone dystrophic changes induced by GC. Our results were in harmony with Derakhshanian et al. ${ }^{[36]}$ who reported a decrease in trabecular as well as cortical thickness coincided with marked decline in osteoblasts number in rats treated with glucocorticoids. Prednisolone administration was found to induce apoptosis of osteoblasts and osteocytes leading to repression of bone formation and low $\mathrm{BMD}^{[37,38]}$. Regarding cortical thickness there was a highly significant decrease in the glucocorticoids treated group compared to control group. The previous data were in concurrence with Kozai et al., ${ }^{[39]}$ who stated that steroid treatment significantly reduced the bone mineral constituents and density. Regarding the mean osteoblastic number there was a highly significant decrease in group IV animals, while the mean number of osteoclast was significantly increased compared to control group.

Walsh $^{[40]}$ demonstrated that glucocorticoid induced osteoporosis. It increases resorption by increasing osteoclast lifespan inducing osteoblast and osteocyte apoptosis that explain the decrease in the mean osteoblastic number and presence of some empty lacunae. In addition, Feng et al. ${ }^{[41]}$ confirmed our results stated that glucocorticoid inhibits the differentiation of mesenchymal precursor cells into osteoblasts

Faintly stained areas with irregularly arranged collagen fibers of bone matrix were also noticed in mallory trichrome 
stained sections denoting defect in mineralization and lack of collagen in these areas. Lane et al. ${ }^{[42]}$ confirmed our results that glucocorticoid treatment results in generation of areas of hypo mineralized bone.

Examination of caspase- 3 stained sections obtained from the femur of this group revealed strong positive reaction of osteocytes to caspase-3 which indicated osteocytes apoptosis as reported by others ${ }^{[37,38]}$ who found that prednisolone administration induces apoptosis of osteocytes.

In this study glucocorticoid treated group showed a sharp obvious drop in osteopontin (OPN) protein expression. This result was in agreement with Shady and Nooh $^{[34]}$. Osteopontin is an extracellular protein synthesized by many cell types including fibroblasts, preosteoblasts, osteoblasts and osteocytes ${ }^{[33]}$. OPN expression may show bone genesis or resorption. Its role is related to the function of the cells linked to the particle matrix. Still, this double action of OPN is uncertain ${ }^{[44]}$. The finding indicated decreased osteogenesis as osteopontin is a versatile protein considered to play a vital role in bone genesis ${ }^{[45]}$.

Glucocorticoids (GCs) negatively affect bone through multiple pathways; proinflammatory cytokines induce bone resorption, reduce bone formation and induce muscle dissipation $^{[4,5]}$. Glucocorticoids also cause osteoblastic dysfunction by shortening the period in which the osteoblasts work actively to form the bone matrix ${ }^{[6]}$. Kasem et al. ${ }^{[7]}$ stated that the chief role of glucocorticoids is inhibition of bone formation by alteration of differentiation and action of many cells types, modification of transcription of many of the genes organize the synthesis of matrix components by osteoblasts, such as type 1 collagen and osteocalcin (OC) and inhibition of the production of prostaglandins such as PGE2 which normally stimulate collagen and noncollagenous protein synthesis.

In the present study, the main serum calcium level in glucocorticoids treated group was significantly decreased in comparison to control group; this was in harmony with a study conducted by Abdel-Kader et al ${ }^{[46]}$ who stated that glucocorticoids reduced $\mathrm{Ca}$ level in the serum of osteoporotic animals. Banji et al.$^{[47]}$ added that glucocorticoids had damaged $\mathrm{Ca}$ and $\mathrm{P}$ balance. The reduction in $\mathrm{Ca}$ serum level was rendered to increased renal discharge and changing in their transport through the brush border membrane. Glucocorticoids act also on calcium and bone metabolism by disturbing vitamin $\mathrm{D}$ metabolism. They reduce 1, 25-dihydroxyvitamin $\mathrm{D}$ receptors in bone leading to osteoporosis ${ }^{[48]}$ or they decreased intestinal calcium absorption ${ }^{[49]}$.

The present finding showed that glucocorticoids significantly increased the level of ALP in the serum compared to control groups. Increasing bone damage and fracture risk was displayed by increase in ALP serum leve ${ }^{[50]}$, as well as in osteoporosis ${ }^{[5]}$. However, Elshal et $a l .{ }^{[51]}$ found that glucocorticoids reduced serum ALP by $16 \%$ short term treated rats while increase serum ALP in long-term treated rats due to bone turnover.
Regarding glucocorticoids and teriparatide treatedgroup, irregular basophilic cement lines and irregularly arranged lamellae formed of irregularly arranged collagen fibers were observed by $\mathrm{H}$ and $\mathrm{E}$ and mallory trichrome stains, similar findings were noticed by Afifi ${ }^{[52]}$. These irregular cement lines and irregular basophilic areas were attributed to increase the rate of bone resorption over that of bone formation ${ }^{[53]}$.

We found that osteoclast number in glucocorticoids and teriparatide was none significantly lower than that of glucocorticoids treated group. Section of the glucocorticoids and teriparatide- treated group showed negative immune raction to caspase-3. Hodsman et al. ${ }^{[54]}$ stated that terparatide inhibit bone resorption by diminishing the number, function, and life span of osteoclasts. Wang et al. ${ }^{[9]}$ confirmed that teriparatide can diminish the level of the cellular ROS and stimulate osteocytes growth via triggering the protein kinase $\mathrm{B}(\mathrm{PKB})$ pathway. Meantime, the activated $\mathrm{PKB}$ can suppress caspase- 3 proteolytic enzyme and stop the activation of apoptosis cascade.

Glucocorticoids and teriparatide- treated group showed positive osteopontin expression in bone matrix. Asou et al. ${ }^{[55]}$ stated that osteopontin was reported to be produced by osteoblast when they form bone matrix. Consequently, it was proved to accumulate in the mineralized matrix binding strongly to hydroxyapatite and possibly explaining its presence in the bone matrix of the newly formed bone. OPN expression may display bone formation related to cells linked to the particle matrix ${ }^{[44]}$.

Regarding the mean serum calcium level, there was a significant increase in Glucocorticoids and teriparatidetreated group compared to control group. Similarly, Bodenner et al. ${ }^{[56]}$ reported that teriparatide injections do have some effect on serum calcium levels but the increase was mild. Hodsman et al.$^{[54]}$ stated that low percentage was recorded with high calcium serum level during teriparatide adminstration.

Regarding the mean alkaline phosphatase level, there was a highly significant increase in glucocorticoids and teriparatide- treated group in comparison to control group. Canalis et $a l^{[10]}$ demonstrated that teriparatide treatment induced raise in biochemical bone markers as alkaline phosphatase during bone formation. Others also showed that teriparatide was linked with significant increase in ALP AS biochemical markers of bone formation in longstanding treatment ${ }^{[57]}$.

In the present study, Co-administration of LS with glucocorticoids induced a marked histological, morphometrical and biochemical improvement in the bone sections. Similarly, Abdel-Kader et al. ${ }^{[46]}$ stated that oral administration of $\mathrm{L}$. sativum significantly reduced the bone resorption in the femurs of glucocorticoids treated rats. Phytosterols and phytoestrogens found in lipidium sativum proved to be beneficial for treatment of osteoporosis ${ }^{[58]}$, also seeds were demonstrated to help in fracture healing ${ }^{[59]}$ 
The constructive role of lipidium sativum on bone density is most likely due to its high content of calcium ${ }^{[60]}$, its potential to raise serum and liver alpha linolenic acid, docosahexaenoic acid and eicosapentaenoic acid ${ }^{[12]}$, which has been proved to possess useful consequences on bone ${ }^{[13]}$. These properties are in line with formerly revealed advantages of LS seeds on fracture healing ${ }^{[11]}$. It was strongly recommended to be used by high risk people to develop osteoporosis, including patients on GCs therapy and postmenopausal women ${ }^{[51]}$.

In this study, L. sativum ameliorated serum ALP level. It stimulated osteoblast proliferation and bone formation; meantime, it suppressed osteoclast activity and bone damage ${ }^{[46]}$. L. sativum is effective in protection against glucocorticoids induced hypocalcaemia ${ }^{[46]}$.

In addition to the previous histological, morphometrical and biochemical findings, the high cost of triparatide was proved ${ }^{[61]}$, while the LS seeds were cheap and available. The seeds are low-priced and incomparable with other medical treatment for fracture ${ }^{[11]}$.

From the foregoing, it is concluded that Glucocorticoids (GCs) negatively affect the bone. Despite the high cost of teriparatide, it did not achieve the desired protective effect .Whereas LS is cheap, available and its protective effect is promising with no adverse effects. So we recommend the use of LS seeds in high risk patients of osteoporosis, especially patients on GCs therapy.

\section{CONFLICTS OF INTEREST}

There are no conflicts of interest.

\section{REFERENCES}

1. Cosman F, de BeurS J, LeBoffMS et al.: Clinician's guide to prevention and treatment of osteoporosis. Osteoporosis Int. 2014; 25(10):2359-2381.

2. Rossini M, Adami S, Bertoldo F et al.:Guidelines for the diagnosis, prevention and management of osteoporosis. Reumatismo. 201668 (01):1-39

3. Gregório LH, Lacativa PGS, Melazzi AC, Russo LAT: Glucocorticoid-Induced Osteoporosis CCBR Brasil - Center for Clinical and Basic Research. Rio de Janeiro, RJ, Brazil. Arq Brasd Endocrinal Metal. 2006 vol.50/4:793-801

4. DeLUCA H.F. and CANTORNA M.T.: Vitamin D. Its Role and Uses in immunology. F.A.S.E.B. J., 2001;15, pp 2579-85.

5. FAHMI, H M, KAMEL E S, OUIES S M, and ABD EL-NAEEM A F: Role of Alendronate and Alfacalcidol in Protection against Steroid Induced Osteoporosis in Adult Male Albino Rats. Med. J. Cairo Univ., 2017; Vol. 85, No. 1, March: 161-171.

6. GRAZIO S., KORSIC M., AMIC B., et al.: Glucocorticoid-induced osteoporosis review and proposition for prevention treatment guidelines. (Lijecvjesn), 2005;127 (1-2) pp.: 36-43.
7. Kasem MA, Khedr EG, Abdel-Aleem AM,Said AS: Histological Effect of Bisphosphonate, Vitamin D and Olive Oil on Glucocorticoid Induced Osteoporosis (Gio) in Albino Rat. The Egyptian Journal of Hospital Medicine (October 2016) Vol. 65, Page 699- 708

8. Riek AE and Towler DA: "The pharmacological management of osteoporosis". Missouri Medicine. 2011; 108 (2): 118-23.

9. Wang T, Han C, Ma XL, Role of Teriparatide in Glucocorticoid-induced Osteoporosis through Regulating Cellular Reactive Oxygen Species, Orthop Surg. 2018 May; 10(2): 152-159.

10. Canalis E, Mazziotti G, Giustina A et al: Glucocorticoid - induced osteoporosis: pathophysiology and therapy. Osteoporos Int 2007; 18:1319-28

11. Juma A. H.: The effects of Lepidium sativum seeds on fracture-induced healing in rabbits. MedGenMed. 2007; 9: 23.

12. Diwakar B. T., Dutta P. K., Lokesh B. R., Naidu K. A. :Bio-availability and metabolism of $n-3$ fatty acid rich garden cress (Lepidium sativum) seed oil in albino rats. Prostaglandins Leukot Essent Fatty Acids .2008; 78: 123-13

13. Kruger M. C., Coetzer H., de Winter R., Gericke G., van Papendorp D. H. Calcium, gamma-linolenic acid $\mathrm{S}$ and eicosapentaenoic acid supplementation in senile osteoporosis. Aging (Milano) 1998; 10: 385-394

14. Zhang Y., Yu. L, Ao M., Jin W: Effect of ethanol extract of Lepidium eyenii Walp. on osteoporosis in ovariectomized rat. Journal of Ethnopharmacology. 2006; 105(1-2):274-279.

15. Raval B and Ravishankar BK: Analgesic effect of lepidium sativum in experimental animals. Ayu, 2010; 31(3).pp371-373

16. Raish M ,Ahmad A, Al Kharfy K M,Ahmad S R,Mohsen $\mathrm{K}$ etal., Hepatoprotective activity ofLepidium sativumseeds against D-galactosamine lipopolysaccharide induced hepatotoxicity in animal model:BMC Complementary and Alternative Medicine, 2016; 16:501

17. KeskinruzgarA, Bozdag $\mathrm{Z}$, Aras $\mathrm{MH}$, Demir $\mathrm{T}$ and Yolcu U: Teriparatide and Osteonecrosis of the Jaw. J Oral Maxillofac Surg., 2016; 74:68-78

18. Hulley P. A., Conradie M. M., Langeveldt C. R., Hough F. S. Glucocorticoid-induced osteoporosis in the rat is prevented by the tyrosine phosphatase inhibitor, sodium orthovanadate. Bone, 2002; 31: 220-229. 
19. Keirnan JA., Histological and histochemical methods, theory and practice. $2015 ; 5$ th edition. Butterworth- Heinenann.Republike-Press. PVT. Ltd.Delhi.Indi.pp.125.

20. Annemarie K. Leonard, Elizabeth A., Yuliya Klymenko, Yueying Liu, Oleg Kim , Marwa Asem , Kevin McAbee, Matthew J. Ravosa, M. Sharon Stack. Methods in Cell Biology. 2018; Volume 143, Chapter 4, Pages 79-95.

21. Glamoclijaa V, Vilovic K, Saraga-Babic M, Baranovic A and Sapunar D: Apoptosis and active caspase-3 expression in human granulosa cells, American Society for Reproductive Medicine, Fertility and Sterility, 2005; Vol. 83, No. 2, February.

22. Thomas $\mathrm{J} \mathrm{T}$, Thomas $\mathrm{T}$, Immunohistochemical Localization of Osteopontin - A Comparative Study on Periodontally Healthy and Diseased Tooth Root Surface. Periodon Prosthodon. 2017; Vol.3 No.2:11

23. Ayub B.,Wani H, Soukat $\mathrm{S}$ et al. : electron microscopy ,J Environ Life Sci. 2017; Vol. 2 (3): 85-88.

24. Bozzola JJ and Russel LD : electron microscopy, principles and technique for biologist . 1999; Jones and Barlett, Boston, 670p.

25. Kalleny NK: Histological and morphometric studies on the effect of alpha-lipoic acid on postovariectomy osteoporosis induced in adult female albino rats. The Egyptian Journal of Histology.2011;34:139-155

26. Manolagas, SC : Birth and death of bone cells: basic regulatory mechanisms and implications for the pathogenesis and treatment of osteoporosis". Endocrine Reviews. 2000; 21 (2): 115-37

27. Dempster D. W. The impact of bone turnover and bone-active agents on bone quality: focus on the hip.Osteoporos Int., 2002; 13:349-352

28. Legrand E., Chappard D., Pascaretti C., Duquenne M., Krebs S., Rohmer V. et al (2000). Trabecular bonemicroarchitecture, bone mineral density, and vertebral fractures in male osteoporosis. J Bone Miner Res .2002;15: 13-19.

29. Dovio A, Perazzolo L, Osella G, Ventura M, Termine A, Milano E, et al. Immediate fall of bone formation and transient increase of bone resorption in the course of high-dose, short term glucocorticoid therapy in young patients with multiple sclerosis. J Clin Endocrinol Metab 2004, 89(10): 4923-8

30. Bunyaratavej N.: The Poor Osteoblastic Functions Can Correct By teriparatide. J Med Assoc Thai., 2015; 98 (Suppl. 8): S102-S104
31. Rosen CJ, Bilezikian JP :Anabolic therapy for osteoporosis.J Clin Endocrinol Metab. 2001; 86:957-964

32. Rubin MR, Bilezikian JP. The role of parathyroid hormone in the pathogenesis of glucocorticoidinduced osteoporosis: a re-examination of the evidence. J Clin Endocrinol Metab., 2002; $87: 4033-41$

33. Valenta A, Roschger P, Fratzl-Zelman NT, Kostenuik PJ, Dunstan CR, Fratzl P, Klaushofer K : Combined treatment with PTH and OPG increases bone volume and uniformity of mineralization in aged ovariectomized rats. Bone, 2005; 37:87-95

34. Shady AM and Nooh H Z: Effect of Black Seed (Nigella Sativa) on Compact Bone of Streptozotocin Induced Diabetic Rats. Egypt J Histol., March,2010; Vol.33,No.1,:168-17.

35. Saad DA. Mohammad AE and Elgohary SA: Green tea extract suppresses osteoclastogenesis and opposes glucocorticoid-induced osteoporosis in rats. Journal of The Arab Society for Medical Research, 2019, 14:33-4

36. Derakhshanian H, Djalali M, Djazayery A, Nourijelyani K, Ghadbeigi S, Pishva H,Saedisomeolia A, Bahremand A, Dehpour AR): Quercetin prevents experimental glucocorticoidinduced osteoporosis: a comparative study with alendronate. Can J Physiol Pharmacol.2013; 91(5): 380-5

37. Migliaccio S, Brama M, Fornari R, Greco EA, Spera G, Malavolta N :Glucocorticoid-induced osteoporosis: an osteoblastic disease. Aging Clin Exp Res., 2007; 19 (3): 5-10

38. Sosa MI, Jódar E, Saavedra P, Navarro MC, Gómez de Tejada MJ, Martín A, Peña P, Gómez J: Postmenopausal Canarian women receiving oral glucocorticoids have an increased prevalence of vertebral fractures and low values of bone mineral density measured by quantitative computer tomography and dual X-ray absorptiometry, without significant changes in parathyroid hormone. Eur J Intern Med., 2008; 19: 51-56

39. Kozai $Y$, Kawamata R, Sakurai T, Kanno M, Kashima I: Influence of prednisolone-induced osteoporosis on bone mass and bone quality of the mandible in rats. Dentomaxillofac. Radiol. 2009 38(1):34-41.

40. WALSH J.S.: "Normal bone physiology, remodeling and its hormonal regulation." Basic Science, 2014; p. 2-6.

41. FENG M., ZHANG R., GONG F., YANG P., FAN L., NI J., BI W., ZHANG Y., WANG C. and WANG K.: "Protec-tive effects of necrostatin-1 on glucocorticoid-induced osteoporosis in rats." J. Steroid. Biochem. Mol. Biol., 2014; 144: 455-62. 
42. Lane NE, Yao W, Balooch M et al. Glucocorticoidtreated mice have localized changes in trabecular bone material properties and osteocyte lacunar size that are not observed in placebo-treated or estrogen-deficient mice. J Bone Miner Res 2006; 21:466-76.

43. Choi ST, Kim JH, Kang EJ, Lee SW, Park MC, Park YB and Lee SK.: Osteopontin might be involved in bone remodelling rather than in inflammation in ankylosing spondylitis. Rheumatology; 2008; 47(12): $1775-1779$

44. Plabo GM, Pedro HC ,Mingual PM et al.: Immunohistochemical osteopontin expression in bone xenograft in clinical series of maxillary sinus lift. Journal of Oral Science \& Rehabilitation, 2015; Volume 1 | Issue 1, pp 42-50.

45. Perrien DS, Brown EC, Fletcher TW, Irby DJ, Aronson J, Gao GG, Skinner RA, Hogue WR, Feige U, Suva LJ, Ronis MJ, Badger TM and Lumpkin CK,Jr.: Interleukin-1 and tumor necrosis factor antagonists attenuate ethanol-induced inhibition of bone formation in a rat model of distraction osteogenesis. J. Pharmacol. Exp.Ther. Dec 2002; 303(3):904-908

46. Abdel-Kader MS, Gabr GA, Soliman GA, Abdul Samad, Al-Tamimi NA: The Potential protective efeects of vigna radiata and lipidium sativum against bone loss induced by prednisolone acetate in male and female rats. IAJPS. 2017; 4 (05), 1085-1094

47. Banji D, Banji O, Chiluka V, Abbagoni S.: Role of Triticum aestivum extract in glucocorticoid induced osteoporosis in rats. Ind J Exp Biol, 2014; 52:153-158

48. SCHARLA S.H., SCHACHT E. and LEMPERT $\mathrm{U}$ : Alfacalcidol versus plain Vitamin $\mathrm{D}$ in inflammation induced bone loss. J. Rheumatol., 2005; 32, pp.: 26-32.

49. ALI A.A.: Effect of Alendronate sodium (FOSAMAX (on bone of adult male spraguedawley rats under gluco-corticoids therapy. Histological and histochemical studies. The Egyptian Journal of Histology, 2006; 29, pp.: 61-72.

50. Jalava T, Sarna S, Pylkkänen L, Mawer B, Kanis JA, Selby P, Davies M, Adams J, Francis RM, Robinson J, McCloskey E. Association between vertebral fracture and increased mortality in osteoporotic patients. J Bone Miner Res, 2003; 18 Suppl 7:1254-1260.
51. Elshal MF, AlmalkiAL, Hussein HK, Khan JA: Synergistic antiosteoporotic effect of Lepidium sativum and alendronate in glucocorticoidinduced osteoporosis in Wistar rats. Afr J Tradit Complement Altern Med. 2013; 10(5):267-273

52. Afifi OK: Histological Study on the Effect of Fluvoxamine Maleate on the Femur of Adult Male Albino Rat, Egypt. J. Histol. 2010; 33, No. 2, 270-278

53. Seeman E. :Pathogenesis of bone fragility in women and men. Lancet ,May $2002 ; 359$ (9320):1841-1850

54. Hodsman A, Bauer DC, Dempester DW, Dian L and Hanely DA: Parathyroid Hormone and Teriparatide for the Treatment of Osteoporosis. A Review of the Evidence and Suggested Guidelines for Its Use, Endocrine Reviews, 2005; Volume 26, Issue 5, 1 August Pages 688-703

55. Asou Y, Rittling SR, Yoshitake H, Tsuji K, Shinomiya K, Nifuji A, et al.:Osteopontin facilitates angiogenesis, accumulation of osteoclasts, and resorption in ectopic bone. Endocrinology 2001; 142:1325-1332.

56. Bodenner D, Redman C, and Riggs A: Teriparatide in the management of osteoporosis. Clin Interv Aging. 2007; Dec; 2(4): 499-507.

57. Blumsohn A, Marin F, Nickelsen T, Brixen K, Sigurdsson G, González de la Vera J, Boonen S, Liu-Léage S, Barker C and Eastell R; Early changes in biochemical markers of bone turnover and their relationship with bone mineral density changes after 24 months of treatment with teriparatide . Osteoporos Int. 2011; 22:1935-1946.

58. Sirotkin AV, Harrath AH. Phytoestrogens and their effects. Eur J Pharmacol, 2014; 741:230-236.

59. Krishnaraju AV, Rao TVN, Dodda S, Vanisree M, Tsay HS, Subbaraju GV. Assessment of bioactivity of Indian medicinal plant using brin shrimp (Artemia salina) lethality assay. Int J Appl Sci Eng, 2005; 3:125-134.

60. Gokavi, S.S., Malleshi, N.G., Guo, M. Chemical Composition of Garden Cress (Lepidium sativum) seeds and its fractions and use of bran as a functional ingredient. Plant Foods Human Nutr. 2004, 59,105-111.

61. Dong Y, Li Y and Weng X: systemic application of teriparatide for steroid induced osteonecrosis in a rat model. BMC musculoskeletal disorders, 2015; 16:163. 


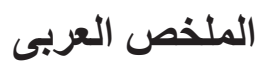

\title{
دراسة مقارنة للتأثير الوقائي المحتمل لحب الرشاد مقابل عقار الترايبار اتيد في هشاثة العظام المستحثة في ذكور خنازير غينيا البالغين
}

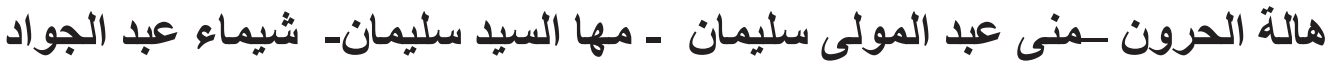 \\ قسم الهستولوجى- كلية الطب- جامعة المنوفيمية
}

المقدمه: ترقق و هثاشة العظام هو مشكلة صحية كبيرة. عقار التر ايبار اتيد هو مشتق من هرمون الغدة الدرقية يستخدم كعلاج مضاد لهشاشة العظام. يستخدم حب الرشاد على نطاق واسع كعلاج عثبي تقليدي لارتفاع ضغط الدم و السكري و اضطر ابات الكلى. ومن المعروف على نطاق واسع بذور حب الرشاد كدو اء بديل جيد للثفاء من كسور العظام. الأهداف: ركزت الأبحاث الحالية على تقييم تأثير حب الرشاد مقابل تأثنير عقار التر ايبار اتيد على مرض هشاثنة العظام الناجم عن الجلوكوكورتيكويد. المواد والطرق: تم تقسيم • ج من خنازير غينيا البالغين بشكل عشوائي إلى ست مجموعات متساوية: المجموعة الضابطة (الماء المقطر)؛ المجمو عة . . ب مجم / كجم حب الرشاد معلقة في الماء المقطر عن طريق الفم بو اسطة أنبوب معدي)، المجمو عة المعالجة من التر ايبار اتيد ع ميكرو غر ام / كيلو غر ام تحت الجلد مرتين أسبو عيًا)، المجموعة المعالجة بالجلوكوكورتيكو يد (0,0 مجم / كجم تحت الجلد)، المجمو عة المعالجة بالجليوكورتيكويدات و السكروكورتيكويد وحب الرشاد تعامل المجمو عة كالمجموعات السابقة فى الجر عات. في نهاية الدر اسة، تم تخدير الحيو انات و التضحية بها. تم استئصسال عظم الفخذ من كل حيو ان للار اسات النسيجية و المناعية . النتائج: إن ترقق العظم الناجم عن الجلوكوكورنيكويد يتجلى في تجاويف فى نسيج العظام الكثيف و انخفاض سماكة العظام القشرية و عدم انتظام سطح العظام. تم الكثف عن انخفاض ألياف الكو لاجين غير النظامية عن طريق صبغة ثلاثي الألوان. الصبغات المناعية، أظهرت هذه المجموعة مناعية إيجابية caspase-cre في الخلابا العظمية و انخفاض في رواسب العظام في مصفوفة العظام. علاوة على ذلك ، كانت هنالك زيادة كبيرة في عدد الخلايا العظمية المرتبطة بتأكل العظام. تم الكشف عن انخفاض كبير في مستوى الكالسيوم في الدم وزيادة في مصل الفوسفاتيز القلوية. إضافة أي من تير ايبار اتيد او حب الرشاد مع جلايكورتيكود ادى الى تحسين التغيرات العظام الكيميائية، النسيجية و المورفومترية. أنها خفضت كل من موت الخلايا العظمية المبرمج وزيادة خلايا تاكل العظمية. كان حب الرشاد أكثر فعالية في تحسين التغييرات التي تحدثها الجلوكورتيكويدات. الاستنتاجات: جلوكورتيكود يسبب ثرقق العظام. على الرغم من ارتفاع تكلفة تير ابار اتيد، فإنه لم يحقق التأثير الوقائي المطلوب. فى حين ان حب الرشاد رخيص الثمن ومتاح وتأثثيره الو اقي بدون آثار ضارة. 